\title{
Confucius in Dutch-Made Learned Journals
}

In August 1687, the Nouvelles de la République des lettres was the first learned journal in Europe to announce the publication of Confucius Sinarum philosophus (1687). The advertisement for the book informed the reader that Philippe Couplet's translation 'can be found in Amsterdam at Henry Desbordes', who, not coincidentally, also happened to be the publisher of the Nouvelles. ${ }^{1}$ Many journals followed with announcements and reviews of the Confucius translation. A month later, the Histoire des ouvrages \& de la vie scavans published the first full review and, in December, the Bibliothèque universelle et historique discussed the work in depth. ${ }^{2}$ Evidently, the subject interested other European countries as well; in October, the Philosophical transactions of London paid considerable attention to the book, followed by Le journal des sçavans of Paris in January 1688. Leipzig's Acta eruditorum, Monatsgespräche from Halle, and Parma's Giornale de'letterati soon joined the ranks. ${ }^{3}$

In the panoply of books discussed by early modern erudite periodicals, Confucius Sinarum philosophus held a special place. ${ }^{4}$ The work was by no means an early modern 'best-seller', as it was never reprinted nor fully translated into even (for the time) the most obvious European languages such as French, German, or Dutch. However, the appearance of numerous reviews soon after publication suggests that the work nevertheless had a considerable impact on the learned European world. In fact, although erudite periodicals reviewed hundreds of publications each year, the Jesuit translation of Confucius was the only book published in 1687 that was discussed by every major journal. In this single act, the learned journals demonstrate clearly how Europe became increasingly preoccupied with China during the last quarter of the seventeenth century. These broadly available publications brought the Middle Kingdom to the fore as an intellectual phenomenon, in part because

1 'Qui se trouvent à Amsterdam, chez Henry Desbordes', in Nouvelles de la République des Lettres (August 1687), p. 910.

2 Histoire des ouvrages des savants (September 1687), pp. 65-79; Bibliothèque universelle et historique (December 1687), pp. 332-39o.

3 Philosophical Transactions of the Royal Society, 16 (1686-1692), pp. 377-378; Le journal des sçavans (January 1688), pp. 167-180; Acta eruditorum (Leipzig: 1688), pp. 254-265; Monatgespräche (Halle: 1688); Giornale de'letterati (Parma: 1688).

4 Peter Burke, Popular culture in early modern Europe (Burlington: Ashgate, 2009), pp. 23-48. 
they focused heavily on the religious and philosophical consequences of the interactions between Europe and China.

Periodicals are ephemeral media, available to a large group of potential readers. Their relative low cost, together with their accessible format, truly made the learned journal 'an agent of change ... disseminating the intellectual effort of the Enlightenment. ${ }^{5}$ For the first time, knowledge that had long been the prerogative of a small circle of intellectual correspondences was made public, whereby the editor functioned as the mediator of information. Arguably, the periodical press played an essential role in the dissemination of images of China in Europe during the second half of the seventeenth century. These journals facilitated access beyond national borders, as well as across cultural, societal, and linguistic boundaries. This chapter seeks to address two main questions relating to the periodical press: how were China and Confucius represented in Dutch learned journals at the end of the seventeenth century, and to what extent did the involvement of Dutch editors and translators, printers and publishers shape the discussion of the Middle Kingdom and its religion and philosophy as an intellectual phenomenon? An analysis of this often-overlooked genre highlights how the perceptions of the Middle Kingdom in the West evolved into a complex and transnational phenomenon.

In answering these questions, I will argue that this recently established erudite press affected the early modern debate on China and its religion and philosophy from both internal and external directions. One development came from within, by way of the authorship, intended readership, and publication of the journals. From the last decades of the seventeenth century onwards, the Dutch-made learned journal was both cause and effect of the growing importance of French as the language of intellectual communication concerning the discussion of China in Western Europe. Most authors and publishers were French Huguenots, who had only just arrived in the Dutch Republic. Their input fundamentally shaped the content of the various learned periodicals. ${ }^{6}$ As to readership: the journals appeared in French and were intended for those who, due to language and intellectual interests, could be considered part of the Republic of Letters. ${ }^{7}$ As such, the increased importance of French as both

5 Ellen Krefting, Aina Nøding, and Mona Ringvej, 'Introduction', in Ellen Krefting, Aina Nøding, Mona Ringve (eds.), Eighteenth-century periodicals as agents of change (Boston and Leiden: Brill, 2015), pp. 1-16, p. 7 .

6 J.J.V.M. de Vet, 'Echoes of the French press in Dutch periodicals in the age of the ancien régime', in Hans Bots (ed.), La diffusion et la lecture des journaux de langue Francaise sous l'ancien régime (Amsterdam and Maarssen: Holland University Press, 1988), pp. 249-262, p. 249.

7 Hans Bots, Henri Basnage de Beauval en de Histoire des ouvrages des savants (Amsterdam: Holland Universiteits Pers, 1976), pp. 38-41; Hans Bots, De Republiek der Letteren. De Europese 


\section{JOUR N A L DE $S$}

\section{$S$ Ç A VA N S} De l'An M. DC. LXXXI.

ParleS. A.D.L.R.

T OME NENVIE ME:

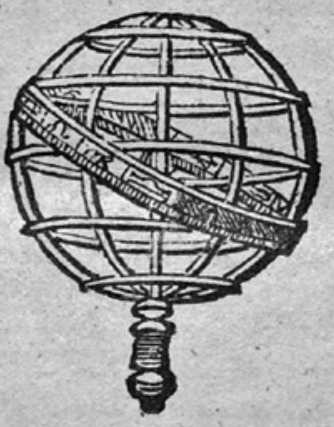

A AMSTERDAM;

Chez PIERRE LE GRANDa M. D C. LXXXII.

FIGURE 27 Journal des sçavans (Amsterdam: Pierre le Grand, 1682) Allard Pierson Amsterdam (xx 19 9) 
lingua franca and cultural focus exerted a considerable influence on the physical distribution and contentual discussion of views on China.

The second influence on the formation of Dutch images of China came about through external circumstances. These circumstances include the increased public visibility of the Chinese Rites Controversy and the emerging comparison between Confucius and European radical thought. These intellectual and political conjunctures weighed heavily on the judgement of religion and philosophy of the Middle Kingdom during the last quarter of the seventeenth century. To understand how the reviews of China and Confucius came into being, it is also useful to consider that which sets them in relationship with other texts. I argue that the journals elucidate how reviewers employed quotation and allusion, genre, and the critical commentary of one text on another to explicitly or implicitly comment on the content, creation, and interpretation of Confucius Sinarum philosophus, as well as on Western European interactions with China in general.

This chapter discusses the Dutch learned journals within the Western European world of print in the last decades of the seventeenth century. Journals functioned as conveyers of intellectual debates in Europe, disseminating knowledge quicker and cheaper than books and more widely than personal correspondence. As such, they offer new insights into the circulation of images of China and Confucius through their reviews of Confucius Sinarum philosophus. Moreover, although the printed medium became increasingly oriented towards France and the international Republic of Letters, the essential role of the Dutch Republic should still be considered. The United Provinces, especially Holland, provided the locale where the intellectual community could converge in spirit and in print.

This chapter first examines how China and Confucius were considered in Dutch-made learned journals before 1687 . Even before the publication of the Jesuit translation of Confucius, periodicals like the Bibliothèque universelle et historique and the Journal des sçavans included discussions about the Middle Kingdom and Confucius. Information that had previously been accessible to only a small number of correspondents was now made public through these discussions. In this process, communication between the editor and contributors facilitated public discourse, and especially the editor functioned as

intellectuele wereld, 1500-1760 (Nijmegen: Uitgeverij Vantilt, 2018), pp.13-32; Anthony Grafton, 'A sketch map of a lost continent. The Republic of Letters', Republics of Letters, 1.1 (2008), pp. 1-18; April Shelford, Transforming the Republic of Letters. Pierre-Daniel Huet and European intellectual life, 1650-1720 (Rochester, NY: University of Rochester Press, 2007), pp. 1-13. 
gatekeeper of the information and its interpretation. This analysis also concerns the actual discussion and review of Confucius Sinarum philosophus in three journals: the Histoire des ouvrages des savants, the Bibliothèque universelle et historique, and the reprinted issue of the Journal des sçavans. By considering the relation between these reviews and the Jesuit translation, it becomes clear that, while the reviews seem rather favourable at first, they nevertheless prove critical in the end; in particular of the Jesuit interpretation of Confucianism.

This chapter then zooms in on one especially contentious element of Confucius Sinarum philosophus: its Tabula chronologica monarchiae Sinicae ('Chronological table of Chinese monarchy'). Learned journals dedicated much attention to the antiquity of China and the notion that Chinese records were supposedly older than the biblical Great Deluge, yet the editors often remained quite circumspect in their descriptions. However, biblical chronology had long concerned European intellectuals, among them Protestant thinkers like Joseph Scaliger, Isaac La Peyrère, and Isaac Vossius. The issue of chronology led to a veritable war of pamphlets between Vossius and his detractor Georg Hornius. This public polemic was facilitated by Dutch printing presses, demonstrating how China and Confucius were deployed as intellectual ammunition, culminating in an often highly appreciative 'philosophical Sinophilia'. The publication of the Jesuit translation of Confucius, and its subsequent discussion in Dutch learned journals, thus marks a watershed moment after which a wealth of substantive and polemic information was made available.

Antoine Arnauld, French Jansenist and one of the first to formulate a clear critique of the Jesuit representation of Confucius is subsequently examined. His writings were discussed extensively in Dutch learned journals. Especially Histoire des ouvrages proved receptive, as the journal and its editor Henri Basnage de Beauval had long-held a contentious relationship with the Society of Jesus. Here, Basnage functioned as mediator between Arnauld and the Jesuits, shaping how the polemic concerning Confucius was presented to the reading public.

In reviewing the Latin translation of Confucius, the editors of the erudite press communicated their first reactions to Chinese philosophy as well as to the argumentation as presented by the Jesuits. When confronted with Confucius, these reviewers now had the tools in hand to juxtapose some of the religious and theological issues of their own times with the ideas of Confucius. This Chinese philosophy carried its own characteristics and meanings, which alone would have been enough to stir up controversy. However, an additional layer of dispute had been added by the very audible Jesuit voice in this debate. Editors, and other authors by way of transtextuality, not only reacted to Confucius's 
texts in and of itself, they also had to navigate the multi-confessional implications of this new information from China.

The erudite periodical originated in the 168os, making new ideas and knowledge, such as the relay of intellectual debates and the announcement of recently published books, more easily accessible. Before their emergence, news about scholarship was primarily available through personal correspondence or through books. In comparison, the new journals made the intellectual debate 'public' by publishing letters that described research results or new observations, while also providing summaries of the latest scholarly publications. Perhaps just as important, the journals also functioned as intellectual equalizers, meaning that 'they allowed readers to share in the labours of the scholarly community' without personal referral or a letter of introduction. ${ }^{8}$ As such, the periodical press extended the European network of scholarly correspondence. Soon, the journals became a powerful tool in the intellectual discourse against traditional structures of 'authority, knowledge, and doctrine' and, as such, amalgamated Europe 'into a single intellectual arena. ${ }^{9}$ In 1710, Francesco Scipione, marquis of Maffei, even claimed that no cultural innovation exerted so immense an impact on Europe as these journals. ${ }^{10}$

As conveyers of intellectual debates in early modern Europe, these journals offered a wealth of information. Various historians have emphasised how the erudite press both reproduced and stimulated the social, institutional, and intellectual environment in which new scholarly discourses first appeared. ${ }^{11}$ As such, learned periodicals may be considered the 'print version' of the Republic

8 Thomas Broman, 'Criticism and circulation of news. The scholarly press in the late seventeenth century', History of Science, $5^{1}$ (2013), pp. 1-26.

9 Israel, The radical Enlightenment 1650-1750, p. 142.

10 In the same year, the marquis of Maffei was among the founders of the literary journal Giornale dei letterati. Between 1737 and 1740, he edited another periodical, entitled Osservazioni letterarie.

11 Hans Bots and Sophie Levie, Periodieken en hun kringen. Een verkenning van tijdschriften en netwerken in de laatste drie eeuwen (Nijmegen: Vantilt, 2006); Hans Bots and Lenie van Lieshout, Henri Basnage de Beauval et l'Histoire des ouvrages des savants, 1687-1709 (3 vol., Amsterdam: APA Holland University Press, 1984); Hans Bots, Pieter Rabus en de 'Boekzaal van Europe', 1692-1702. Verkenningen binnen de republiek der letteren in het laatste kwart van de zeventiende eeuw (Amsterdam: Holland Universiteits Pres, 1974); Hans Bots (ed.), La diffusion et la lecture des journaux de langue francais sous l'Ancien regime/Circulation and 
of Letters: something which is attested to by the journals' own proclamations concerning intended audiences and the social settings in which they should be read. In recent years, scholars have become increasingly attentive to the important role played by the periodical press in the dissemination of knowledge during the second half of the seventeenth century. ${ }^{12}$ Historian Hans Bots has published extensively on the subject of intellectual correspondence and the periodical press in early modern Europe. His work on Henri Basnage de Beauval and Pierre Bayle, and their position and influence within the learned world has been pioneering in an area of scholarship, which touches upon both intellectual history as well as the history of print.

The periodical press in general, and the erudite journal in particular, open up new insights into the dissemination and interpretation of the Middle Kingdom in early modern Western Europe. The genre distributed knowledge more rapidly and altogether more cheaply than books, and 'more widely than correspondence. ${ }^{13}$ The subjects discussed ranged from politics, natural philosophy, biology, and the invention of machinery to languages, costumes, and foreign countries. As the editor of Histoire des ouvrages des savants emphasised: 'We insert here all the circumstances regarding the scholars about whom we will have knowledge. ${ }^{14}$ Because of these broad objectives, there is no generally used term to unequivocally describe the early modern periodical. However, at its most fundamental level, the genre could be defined as 'a publication that was intended to appear more or less regularly for general sale, possessing a recognisable degree of continuity of external form, and containing a plurality

Reception of Periodicals in the French Language in the 17th and 18th Centuries (Amsterdam and Maarssen: APA Holland University Press, 1988).

12 Eric Palmer, 'Less radical Enlightenment. A Christian wing of the French Enlightenment', in Steffen Ducheyne, Reassessing the radical Enlightenment (New York: Routledge, 2017), pp. 197-222; Ingemar Oscarsson, 'For the laity, as well as for the learned. Some themes and structures in the system of the early modern learned periodicals', in Krefting, Nøding, and Ringvej (eds.), Eighteenth-century periodicals as agents of change, pp. 46-61; Thomas Munck, 'Translating Enlightenment. European influences and Danish perceptions of identity in the press in the later eighteenth century', in Hendrik Horstbøll and Knud Haakonssen (eds.), Northern antiquities and national identities. Perceptions of Denmark and the north in the eighteenth century (Copenhagen: Det Kongelige Danske Videnskabernes Selskab, 2008), pp. 227-25o.

13 Neil Kenny, The uses of curiosity in early modern France and Germany (Oxford: Oxford University Press, 2004), pp. 266.

14 'Nous insererons icy toutes les circonstances qui regarderont les Scavans dont nous aurons connoissance', Henri Basnage de Beauval, Histoire des ouvrages des savants (September 1687), p. 3 . 
of items, as opposed to the single event to which one-off broadsheets and pamphlets had often been devoted'.15

Early modern learned journals were issued by well-established publishers, who used them to inform readers about recently published books, and especially those books that were sold in their shops. While Confucius Sinarum philosophus was published by Daniel Horthemels in Paris, its review in the Histoire des ouvrages des savants explicitly mentioned that it could be procured 'at Reinier Leers in Rotterdam', who (of course) was the publisher of the journal. Publishers often worked in cooperation: the Journal des sçavans was issued by Pierre le Grand and Daniel Elzevier, and Abraham Wolfgang, Hendrick Boom, Abraham van Someren, Johannes II Janssonius van Waesberge, the widow of Joannes van Someren, the widow of Dirk I Boom, Gillis Janssonius van Waesberge, and Petrus van Someren were together responsible for the Histoire des ouvrages.

The content was mainly the responsibility of the editor, who performed a fundamental task in collecting, assembling, and editing news and reviews. The editorial process consisted of sorting the papers to accept and reject, which was not only a responsible task, but a difficult one. In 1772, Albrecht von Haller of the Göttigsche Gelehrte Zeitung wrote that the editor must be a master of many subjects, understanding many languages and many sciences. He added that, if the editor was not up to this task, it would be better if the job were assigned to a group of scholars. ${ }^{16}$ Editors thus tended to make a selection, primarily owing to the fact that most journals were an individual enterprise. They also tried to improve the editorial process by introducing collective reviews. ${ }^{17}$ The Journal des sçavans even sent editors abroad to report interesting events from the scholarly world that happened there. ${ }^{18}$

In the Dutch Republic, journals were generally printed in duodecimo, using a relatively fine quality of paper. Illustrations were often included, mainly to 'provide clarity to ... prose, providing access to useful information that was

15 Jean-Pierre Vittu, “Le peuple est fort curieux de nouvelles". Information périodique dans la France des années 169o', Studies on Voltaire and the Eighteenth Century, 32 (1994), pp. 105-144; Wolgang Martens, Die Botschaft der Tugend. Die Aufklärung im Spiegel der deutschen Moralischen Wochenschriften (Stuttgart: Metzler, 1968), pp. 15-20.

16 Albrecht von Haller, Sammlung kleines Hallischen Schriften (Berg: E. Haller, 1772), p. 121.

17 David A. Kronick, 'Devant le deluge' and other essays on early modern scientific communication (Lanham and Oxford: The Scarecrow Press, 2004), pp. 105-106.

18 Harcourt Brown, 'History and the learned journal', Journal of the History of Ideas, 33 (1972), pp. $365-378$. 
otherwise invisible. ${ }^{19}$ Each issue also reviewed dozens of books. In 1687 , the Bibliothèque universelle reviewed 177 books in 12 issues across four volumes. These were ordered in various categories such as politics, medicine, theology, and 'nouvelles editions de quelques anciens auteurs'. Furthermore, books in a variety of languages were discussed: in 1687 alone, reviews were published for books originally in Latin, French, English, Dutch, German, Spanish, and Hebrew.

In the first week of January 1665 , the French writer Denis de Sallo, Sieur de la Coudraye, published Europe's first learned journal, the Journal des sçavans, in Paris. Jean-Baptiste Colbert, ministre de l'économie and founder of the Académie Royale des Sciences, supported the publication. In general, the publication aimed to inform the reader about everything that happened in the scholarly community of Europe. The journal was mostly dedicated to the review and announcement of books in every field of knowledge, although the editors were careful when it came to religious or political publications. ${ }^{20}$ Interest in the journal rose immediately and reprints soon appeared in Brussels, Cologne, Leipzig, and Amsterdam. The Amsterdam publisher, Pierre le Grand, even adapted the publication to appeal more to the wishes of his Dutch consumers by adding articles. In the Dutch Republic, the Journal was also smaller in size: duodecimo compared to the French quarto. ${ }^{21}$

The London-based the Philosophical transactions, first appeared three months later, 'giving some account of the present undertakings, studies, and labours of the ingenious in many considerable parts of the world.' ${ }^{22}$ As the monthly publication of the Royal Society, the journal adhered to its ideals by advocating experiment and observation over a discussion of theory. ${ }^{23}$ The journal therefore focused primarily on scientific discovery, which makes its review of Confucius Sinarum philosophus remarkable. In 1682, the Acta eruditorum became the first scientific journal of the German-speaking lands. It was founded in Leipzig by Otto Mencke, in collaboration with Gottfried Wilhelm Leibniz. Acta was published by Johann Friedrich Gleditsch and appeared monthly. Similar to the Journal des sçavans, the Acta contained excerpts of new writings, reviews, small essays, and general notes. Most of these were devoted

19 Meghan C. Doherty, 'Giving light to narrative. The use of images in early modern learned journals', Nuncius, 30.3 (2015), pp. 543-569, p. 543.

$20 \quad$ Kronick, 'Devant le deluge', pp. 120-129.

21 Jean-Pierre Vittu, 'La formation d'une institution scientifique. le Journal des sçavans de 1665 à 1714', Journal des sçavans, 1.1 (2002), pp. 349-377.

22 Philosophical Transactions of the Royal Society, 1 (1665-1666), title page.

23 David A. Kronick, 'Notes on the printing history of the early "Philosophical Transactions", Libraries and Culture, 25.2 (1990), pp. 243-268. 
to the natural sciences and mathematics. Interestingly, the Jesuit translation of Confucius also merited a review in this journal. ${ }^{24}$

The last quarter of the seventeenth century saw the publication of many new journals, all of which would review Confucius Sinarum philosophus. ${ }^{25}$ The Dutch Republic produced a greater number of these than any other European country. While the intellectual Republic of Letters may have transcended many boundaries, the United Provinces performed an invaluable service to European scholarship by 'fostering and habitually practising a free trade in the circulation of erudition. ${ }^{26}$ The trade in printed works benefitted from a lack of political and religious control, which was the result of the country's unusual governmental structure and its lack of a state religion. ${ }^{27}$ These conditions became such a trademark that the editor of the Bibliothèque universelle et historique even believed that he would surpass his rivals by the simple fact that he worked in Amsterdam, 'as one finds oneself in a country of freedom.' ${ }^{28}$ The quality of Dutch news and printing was, moreover, highly esteemed and the whole of Europe purchased books in the shops of Amsterdam, Leiden, and The Hague. Subsequently, Dutch publishers and booksellers truly performed a 'pivotal function ... as intermediary in the international exchange of news and information. ${ }^{29}$

The first learned journal of the Dutch Republic, the Nouvelles de la République des lettres was published in March 1684, edited by 'philosopher of

24 H. Laeven, The 'Acta eruditorum' onder redactie van Otto Mencke. De geschiedenis van een internationaal geleerdenperiodiek tussen 1682 en 1707 (Amsterdam: APA Holland University Press, 1989).

25 See, for an overview of eighteenth-century learned journals: Le gazetier universel, http:// gazetier-universel.gazettes18e.fr/, last accessed 23 August 2021; see also Henry Carrington Bolton, A catalogue of scientific and technical periodicals, 1665-1895 (Washington: Smithsonian Institution, 1897); Robert M. Gascoigne, $A$ historical catalogue of scientific periodicals, 1665-1900 (New York and London: Garland Publishing Inc., 1985); David A. Kronick, A history of scientific \& technical periodicals (New Jersey: The Scarecrow Press, 1979).

26 Graham Gibb, 'The role of the Dutch Republic as the intellectual entrepôt of Europe in the seventeenth and eighteenth centuries', BMGN - Low Countries Historical Review, 83.3 (1971), pp. 323-349, p. 327 (my emphasis).

27 Paul Hoftijzer, 'The Dutch Republic. Center of the European book trade in the 17th century', European History Online, www.IEG-EGO.eu, last accessed 23 August 2021; M.E.H.N. Mout, 'Limits and debates. Comparative view of Dutch toleration in the sixteenth and early seventeenth centuries', in Christiane Berkvens-Stevelinck, Jonathan Israel and G.H.M. Postumus Meyies (eds.), The emergence of tolerance in the Dutch Republic (Leiden, New York, Köln: Brill, 1997), pp. 37-48.

28 'Comme on se trouve en un pais de liberté', Bibliothèque universelle et historique (January 1686), p. 3.

29 Hoftijzer, 'The Dutch Republic'. 
Rotterdam' Pierre Bayle. ${ }^{30}$ It appeared monthly in French. The Nouvelles was singularly devoted to the discussion of books, and thus can be considered the first 'book review' journal. In 1686, the Bibliothèque universelle et historique followed its example, edited by scholar and radical thinker Jean Leclerc. ${ }^{31}$ Born in Geneva, Leclerc became famous for his radical ideas about promoting a critical interpretation of the Bible. He left his native Switzerland for London, finally moving to Amsterdam due to the political instability in England and his own radical Protestantism. In the Dutch Republic, his friendship with Philipp van Limborch brought him closer to the Remonstrant theology. Indeed, he also owed his long-term appointment as professor of philosophy and Hebrew at the Remonstrant seminary to Van Limborch. ${ }^{32}$ The publication of Leclerc's journal was a joint effort between a number of printers and publishers, including Abraham Wolfgang and Johannes II Janssonius van Waesberge. ${ }^{33}$ It appeared monthly, providing detailed reviews of recent books, paying special attention to theology, ecclesiastical and civil history, philosophy and science. Even though the Bibliothèque was published in French, almost 20 per cent of its reviews were devoted to English books, demonstrating the journal's international aim. ${ }^{34}$

1687 saw the publication of another Dutch learned journal: Henri Basnage de Beauval's the Histoire des ouvrages des savants. Beauval, a Huguenot historian and sometimes lexicographer, had left France for Rotterdam in 1687. After arriving in the United Provinces, he wasted little time and, in September of the same year, issued the first edition of his periodical in collaboration with Reinier Leers. In essence, the Histoire des ouvrages functioned as a sequel to Pierre Bayle's the Nouvelles de la République des lettres, with the change in title

\footnotetext{
$30 \quad$ Nouvelles de la république des lettres (March 1684).

31 Hans Bots (ed.), De 'Bibliothèque universelle et historique' 1686-1693. Een periodiek als trefpunt van geletterd Europa (Amsterdam and Maarssen: APA Holland University Press), 1981.

32 Martin Innis Klauber, The context and development of Jean LeClerc's views on the subject of religious authority', PhD thesis: University of Wisconsin-Madison, 1982, pp. 47-53.

33 Abraham Wolfgang, widow of Dirk I Boom, Hendrick Boom, Abraham van Someren, Johannes II Janssonius van Waesberge, widow of Joannes van Someren, Gillis Janssonius van Waesberge, Petrus van Someren.

34 Jean Leclerc's contacts with the English philosopher John Locke facilitated the provision of English subjects in the Bibliothèque. From 1686 onwards, Locke regularly wrote for the journal, and his Essay concerning human understanding was published in the edition of 1687; Hendrika J. Reesink, L'Angleterre et la littérature anglaise dans les trois plus anciens périodiques français de Hollande de 1684 à 1709 (Paris: H. Champion, 1931); Hans Bots, 'Jean Leclerc as journalist of the Bibliotheques. His contribution to the spread of English learning on the European continent', in G.A.M. Janssen and F.G.A.M. Aarts (eds.), Studies in seventeenth-century English literature, history and bibliography (Amsterdam: Rodopi, 1984), pp. 53-66.
} 
being merely cosmetic to avoid trouble with its former publisher: 'One would undoubtedly like to know why I have not continued under the same title as Mr. Bayle'.35

The intended audience for erudite journals consisted mainly of savants or érudits. In practice this referred to learned men and scholars: women only became active as editors from the eighteenth century onwards. ${ }^{36}$ Hans Bots has reconstructed the potential readership for these journals by way of the correspondence of the editors, as well as by examining 179 contemporary book auction catalogues. ${ }^{37}$ Bots's findings indicate that the readership of learned journals could be divided into two broad categories: academic scholars, and less specialised but nevertheless interested and educated general readers. ${ }^{38}$ The erudite press was indeed the prerogative of the educated; professors, philosophers, ministers, magistrates, and liberal professionals, such as solicitors and medical practitioners, made up the majority of readers. Thirty per cent of auction catalogues examined by Bots revealed an ownership of the Bibliothèque universelle et historique, while 20 per cent indicated ownership of the Nouvelles de la République des lettres. Basnage's the Histoire des ouvrages des savants is recorded 26 times ( 15 per cent). In 17 instances, the catalogues indicate simultaneous possession of all three journals. This is not surprising, as their content would have differed considerably and readers perhaps would have wished to compare reviews. ${ }^{39}$

As to the cost of learned journals: while these publications would not have been affordable to large parts of the population, their prices were nevertheless relatively modest. The particulierenboeken of Leiden bookseller and publisher

35 'L'on voudra sçavoir aussi sans doute, pourquoy je n'ay pas continué sous le même titre de Mr. Bayle', Histoire des ouvrages des savants (September 1687), preface; Lenie van Lieshout, 'De materiaalvoorziening voor de Histoire des ouvrages des savants', Documentatieblad Werkgroep Achttiende Eeuw (1989), pp. 97-137.

36 Anne Good, 'The construction of an authoritative text. Peter Kolb's description of Khoikhod at Cape of Good Hope in the eighteenth century', in Peter Mancall (ed.), Bringing the world to early modern Europe. Travel accounts and their audiences (Leiden and Boston: Brill, 2004), pp. 61-94, p. 92; R. Schenkeveld-van der Dussen, 'Women's writing from the Low Countries 1575-1875', in Lia van Gemert etc. (eds.), Women's writings from the Low Countries 1200-1875. A bilingual anthology (Amsterdam: Amsterdam University Press, 2010), pp. 39-63; Suzan van Dijk, 'Vrouwen en hun Republiek der Letteren. Internationale contacten tussen schrijfsters vóór de feministische golven', Tijdschrift voor vrouwenstudies, 17 (1996), pp. 235-253; Lotte Jensen, Bij uitsluiting voor de vrouwelijke sekse geschikt. Vrouwentijdschriften en journalisten in Nederland in de achttiende en negentiende eeuw (Hilversum: Verloren, 2001), pp. 26-27.

37 Bots, Henri Basnage de Beauval, pp. 38-41.

38 Bots, Henri Basnage de Beauval, pp. 38-41.

39 Bots, Henri Basnage de Beauval, pp. 38-41. 
Jordaan Luchtmans show that both the Histoire des ouvrages and the Acta eruditorum could be bought for five stuivers. ${ }^{40}$ This relative affordability allowed savants to gather knowledge about books they either could not afford to buy, or which simply could not be acquired. ${ }^{41}$ This last concern would most likely have applied to Confucius Sinarum philosophus. The book was published in Paris in only a single edition and its availability in the Dutch Republic would have, therefore, been limited.

Those active in the production of learned journals had often only recently arrived in the Dutch Republic.42 In the decades surrounding 160o, 'a veritable exodus of human capital' had left the Southern Netherlands to establish itself in the United Provinces, often as printer, publisher, or bookseller. After 1685, another wave of immigration occurred when Louis XIV revoked the Edict of Nantes (1598), to be replaced with the Edict of Fontainebleau, which led to widespread persecution of Huguenots in France. In the second half of the seventeenth century, tens of thousands of French Protestants settled in the United Provinces, leading Pierre Bayle to proclaim the country as 'the great Ark for refugees' ${ }^{43}$ Again, among them were many printers, publishers, and booksellers, who brought with them a wealth of professional skills. These exiles also introduced new and innovative genres, such as the newspaper and the learned journal. Yet, it was the Dutch political, economic, and cultural climate that made all this possible, providing a relatively safe haven for anyone wishing to shine their light on the potential controversial issues about China and its diverse and often contentious religion and philosophy.

Latin was already losing ground as the language of European scholarly communication, and the Huguenot influence on the periodical press solidified the introduction of French as the means of intellectual discourse. ${ }^{44}$ A direct consequence of the growing importance of French as the language of international erudite communication was that Dutch presses now produced for a much larger area. The period around 1700 is marked by France's political and

40 Bibliotheek van de Vereniging ter Bevordering van de Belangen des Boekhandels te Amsterdam, 'Boeck van Particulieren 1702-1712, Archief Luchtmans 32, f. 34r', in Bots, Henri Basnage de Beauval, p. 8o.

41 Anne Goldgar, Impolite learning. Conduct and community in the Republic of Letters, $1680-$ $175^{\circ}$ (London and New Haven: Yale University Press, 1995), pp. 55-56.

42 David van der Linden, Experiencing exile. Huguenot refugees in the Dutch Republic, 16801700 (Farnham: Ashgate, 2015).

43 'La grande arche des réfugiés', Pierre Bayle, Dictionnaire historique et critique (vol. 3, Amsterdam: Pierre Brunel etc., 1740), p. 25; Peter Burke, Exiles and expatriates in the history of knowledge, 1500-200o (Waltham: Brandeis University Press, 2017), pp. 39-82.

44 Peter Mancall, Bringing the world to early modern Europe. Travel accounts and their audiences (Leiden and Boston: Brill, 2012), p. 93. 
cultural hegemony in Europe, which should be understood not just in national terms, but also very much in cultural terms. In early modern and pre-national Europe, 'French' was not a political or national entity, but the international and cross-boundary language of letters and culture. This language, both in the literal sense and as conveyer of culture, became predominant in much of Western Europe, a situation to which the printers and publishers of the Dutch Republic quickly adapted. ${ }^{45}$

While many Dutch-made books on China had previously been published in the Dutch language, in the second half of the century an exceeding number appeared in French. ${ }^{46}$ Books such as those by Jesuit missionary Louis Le Comte, and the Formosan imposter George Psalmanazar, appeared simultaneously in Dutch and French; meanwhile, the aforementioned adaptations of Confucius Sinarum philosophus by Jean de Labrune and Simon Foucher were solely published in French. ${ }^{47}$ The learned journals published in Amsterdam and Rotterdam also appeared in French. In addition to being written in French, they also discussed many 'French' subjects, based on French sources and/ or concerning French issues. And to no surprise, as Pierre Bayle and Henri Basnage were born and raised in France, printing and publishing were mostly carried out by fellow Huguenot refugees, and readership essentially consisted of those who could read French. ${ }^{48}$

Of course, the French Jesuit mission to China would also play an increasingly important role in the dissemination of knowledge about the Middle Kingdom in Europe from the middle of the 168 os onwards. As many as 50 French missionaries travelled to China during the reign of the Kangxi Emperor. They were sent by Louis XIV, and their work in astronomy, geometry, mathematics, and arithmetic soon found favour with the Chinese emperor. The reports they sent back had, therefore, a pronounced impact on the transmission of knowledge about

45 Bethany Wiggin, Novel translations. The European novel and the German book, 1680-1730 (Ithaca: Cornell University Press, 2011), pp. 1-14.

46 Pascale Casanova, World Republic of Letters (Cambridge: Harvard University Press, 2004), pp. 57-6o; Darnton, The forbidden best-sellers of pre-revolutionary France, p. 9.

47 George Psalmanazar, Description de ïile Formosa en Asie ... Dressée sur les mémoires du sieur George Psalmanaazaar. Par le sieur N.F.D.B.R. (Amsterdam: Roger Etienne, 1705); George Psalmanazar, Beschryvinge van het eyland Formosa in Asia ... uit de gedenkschriften van den hr. Georgius Psalmanaazaar ... t'zamengestelt.... Door d'hr. N.F.D.B.R. (Rotterdam: Pieter van der Veer, 1705); see also Michael Keevak, The pretended Asian. George Psalmanazar's eighteenth-century Formosan hoax (Detroit: Wayne State University Press, 2004).

48 Pierre Bayle left France in 1681 and Henri Basnage de Beauval did the same in 1687. Jean Leclerc was neither Huguenot nor French, but came from Geneva. However, his exile was religious, since he settled in Amsterdam due to the uncongenial nature of the theological atmosphere in Switzerland, see Van der Linden, Experiencing exile. 
China to Western Europe during the late seventeenth century. Information about the Middle Kingdom was quickly disseminated through the newly established periodical press of the United Provinces, which made sure that the Dutch-made journals on China truly became, in the words of Margaret Jacobs, 'strangers nowhere in the world' 49

\section{2 \\ The Erudite Press and China before 1687}

As we have seen, China had become increasingly familiar to European readers in the decades preceding the publication of Confucius Sinarum philosophus. Most knowledge was made available through books, yet, from the middle of the seventeenth century onwards, the importance of the periodical press grew. By reviewing books that contained information on China, the learned journal spread the word on the Middle Kingdom farther and wider than any book ever could. In the year before the publication, and review, of the Jesuit translation of Confucius, the Bibliothèque universelle et historique mentioned China eight times, while the Journal des sçavans did so once. Interestingly, both journals mentioned China in discussions of books not solely about China: 'The $5^{\text {th }}$ chapter [of Urbain Chevreau's Histoire du monde] contains a description of China, of its antiquity, of its extent, of its riches, and of its most beautiful towns. 50

Pierre Bayle's the Nouvelles de la République does the same, presenting interesting content in the form of a transcription of a written letter: 'Extract from a letter written at Versailles to the author of the Nouvelles, on 19 March last, touching upon a few Chinese manuscripts. ${ }^{51}$ This letter demonstrates the pivotal role of the newly established learned journals in disseminating information about China. Knowledge that before was only accessible to a small circle of correspondents was now published on the pages of erudite periodicals. The communication between the editor Bayle and the contributor facilitated this public conversation, in which the former functioned as gatekeeper

49 Margaret C. Jacob, Strangers nowhere in the world. The rise of cosmopolitanism in early modern Europe (Philadelphia: University of Pennsylvania Press, 2006), pp. 65-94; Diderot and d'Alembert, Encyclopédie, 'cosmopolitan', p. 404.

50 'Le ch. V. contient la description de la Chine, de son antiquité, de son étenduë, de ses richesses \& de ses plus belles villes', Bibliothèque universelle et historique (February 1686), pp. 183-193, p. 192.

51 'Extrait d'une lettre écrite de Versailles à l'Auteur de ces Nouvelles le 19. Mars dernier, touchant quelques Manuscrits Chinois', Nouvelles de la Republique des lettres (April 1686), pp. 428-429. 
of information and interpretation by choosing which announcements and reviews to print.

This letter concerned the French residency of Philippe Couplet and his Chinese companion Michael Shen Fuzong. As discussed in the previous chapter, Couplet and Shen left China in 1681 for a propaganda tour of Europe. After arriving in Holland on 8 October 1683, Couplet and Shen travelled much of western Europe together. ${ }^{52}$ In September 1684, they arrived in Versailles where they met with Louis XIV. ${ }^{53}$ Flemish Jesuit Petrus-Thomas van Hamme narrated this royal visit, an account of which also appeared in the Mercure galante of October 1684. Its description demonstrated to the readers of both journals how both Couplet and his Chinese visitor were deserving of the highest honour, emphasising (among other things) the esteem in which Shen's native country was held:

The other day, they went to see the king eat, and as soon as they entered, His Majesty ordered the people near him to make room, and had Father Couplet and Sir Michael [Shen] come to his table. He was sitting at the table with the dauphin and dauphiness. He spoke with Father Couplet, asking him, among other things, whether he had seen the fountains turned on. Father Couplet replied that he had not and that he was not worthy of such honour. The king however, stated that he should see it, giving orders that when they would go into the gardens, all the fountains should be turned on. This surely has been a great, even the most important, honour which the king bestowed upon Father Couplet, since these fountains were only turned on in honour of ambassadors or princes of high rank. In the presence of all those assembled, the king had Sir Michael [Shen] recite loudly in Chinese the Pater Noster, the Ave Maria, and the Credo. After that, Madame la Dauphiness - who the day before had seen the little ivory sticks that s/Sir Michael [Shen] used to eat with advised the king to watch him eat in Chinese fashion. The king immediately ordered to give him a golden plate with food to be eaten with his little ivory sticks, and Sir Michael stood at the table of His Majesty and, together at one table with the king, demonstrated eating some food with his little sticks. ${ }^{54}$

$5^{2}$ Foss, 'The European sojourn of Philippe Couplet and Michael Shen Fuzong', pp. 121-142.

53 For a list of questions posed by Louis XIV and his Jesuit confessor Francois La Chaise to Philippe Couplet and Michael Shen Fuzong see: Virgile Pinot, Documents inédits relatifs à la connaissance de la Chine en France de 1685 à 1740 (Paris: Paul Geuthner, 1932), pp. 7-9.

54 'Des anderen daghs sijn sy ghegaen om den Coninck te sien eten, ende soo haest sy inquaemen, dede den Coninck het volck verschuyven, pater Couplet ende heer Michael 
Couplet and Shen left France for Rome in October 1684, yet Louis XIV proved so enamoured with the Jesuit and his Chinese companion that, two years later, he requested their return. The letter printed in the Nouvelles de la République was written just before this second meeting, yet the content related to the first visit: 'It was approximately 18 months ago that ambassadors of China were here..55

Although recorded anonymously in the Nouvelles, the original correspondence points to French doctor and numismatic Pierre Raissant as the author. ${ }^{56}$ Raissant often corresponded with Pierre Bayle about announcements and reviews, for instance, 'concerning the book De l'utilité des voyages by Mr. Baudelot. There are a few good things, and a lot of bad ones. Its style is detestable. ${ }^{57}$ Raissant's letter to Bayle contained a private (although not explicitly confidential) part as well as a segment intended to be made public: 'I have come to learn of some news that deserves to be known by all "amateurs of science" (amateurs des sciences). ${ }^{58}$ How Raissant had learned of Couplet and Shen's return to France is unclear from the printed letter, but according to

tot aende tafel commen. Den Coninck sat aen tafel met den Dolphijn ende de Dolphine; hy sprack met pater Couplet, hem, onder ander, vraeghende of hy de fonteynen hadde sien springhen; waerop pater Couplet antwordende, dat neen en dat hy dierghelycke eere niet weerdigh en was, seyde den Coninck, dat hy dien soude sien, recommanderende, dat, als sy den hof souden gaen sien, men alle de fonteynen soude doen springhen. 'T welck voorwaer eene groote, jae de principaelste eere is gheweest die pater Couplet vanden Coninck heeft ontfanghen, mits dese fonteynen maer en springhen ter eeren van ambassadeurs ofte groote princen. Den Coninck dede heer Michael met luyder stemme, ten bywesen van alle de omstanders, lesen in 't Chinois den Pater noster, Ave Maria, ende Credo. Daernaer madame de Dolphine, die daghs te vooren hadde ghesien de ivoire stoexkens van heer Michael om mede te eten, segghende aenden Coninck, dat hy hem eens moest sien eten op sijn chinois; de Coninck ordonneerde terstont aen hem te gheven eene goude tailloire met spyse om met syne ivore stoexkens te eten, ende heer Michael staende aende tafel vanden Coninck, heeft saemen op eene tafel met den Coninck, eenighe spyse ghenut met syne stoexkens', Het leven van pater Petrus-Thomas van Hamme. Missionnaris in Mexico en in China (1651-1727) (Ghent: Annoot-Braeckman, 1871), pp. 14-15. See also Mercure galant (October 1684), pp. 127-128 and Mercure Galant (September 1684), pp. 211-224.

55 'Il y a environ 18 mois que des ambassadeurs de la Chine estant icy', Pierre Raissant à Pierre Bayle, lettre 540, via www.Bayle-correspondance.univ-st-etienne.fr, last accessed 23 August 2021.

56 Raissant à Bayle, lettre 540.

57 'Du livre De l'itilité des voyages, de Mr. Baudelot. Il y a peu de bonnes choses, et beaucoup de mauvaises. Le style en est detestable': Pierre Raissant à Pierre Bayle, lettre 508 (5 February 1686), www.Bayle-correspondance.univ-st-etienne.fr, last accessed 23 August 2021. C.-C. Baudelot de Dairval's De l'utilité des voyages et de l'avantage que la recherche des antiquitez procure aux scavans (Paris: Pierre Aboüin, 1686) was reviewed in April 1686.

58 'Je viens d'apprendre une nouvelle, qui mérite d'estre sceüe de tous les amateurs des sciences', Raissant à Bayle, lettre 540. 
the private correspondence the numismatic had been working on Louis's cabinet of medallions, 'since, for more than a month, I see the prince [Louis XIV] on a daily basis. ${ }^{59}$ Allegedly, Raissant and the king were on speaking terms, since the former related how he talked to Louis about various subjects. ${ }^{60}$

The Nouvelles de la République des lettres reproduced the final third of Raissant's letter almost verbatim. It relates how Louis-August, Duke of Maine (and natural son of Louis XIV) had informed the king about the antiquity of China, and that 'that they [the Chinese] had known all the sciences and the arts first'.61 Raissant goes on to explain that not much is known about China, and that 'it behoves none but a prince, like the king, to have books brought over from China', together with people to translate them. ${ }^{62}$ Supposedly, three hundred Chinese books arrived in Paris, along with two translators in the shape of Philippe Couplet and Michael Shen Fuzong: 'And of this they assure me: that on this present day, almost 3000 Chinese books have arrived in Paris, both of the country's civil history, and of its natural history; of mathematics and other curious subjects, and on top of this, two translators have arrived'.63 The letter thus implies that Couplet and Shen had come to France to serve solely as translators to Louis XIV, which is not only a simplification, but an underestimation, of their real intentions. ${ }^{64}$ The aims of their European trips were obviously numerous, a priority of which was the publication of Confucius Sinarum philosophus. Thus, even though Raissant mentioned that 'that these

59 'Depuis plus d'un mois je vois tous les jours le Prince', Raissant à Bayle, lettre 540.

6o 'Il y a environ huit jours que je luy parlay de l'ouvrage de Monsieur Rou, dont je luy montray mesme une planche luy faisant entendre le merite de cet ouvrage et le sujet qui en avoit causé la surpression, il mordonna d'en à Monseigneur le chancelier chez lequel je fus des le lendemain', Raissant à Bayle, lettre 540.

61 'Quíls avoient connu les sciences et les arts tous des premiers', Raissant à Bayle, lettre 540. On the Chinese interests of Louis-August de Bourbon, duc du Maine and legitimated natural son of Louis XIV and Madame de Montespan see Christopher M.S. Johns, China and the church. Chinoiserie in global context (Oakland: University of California Press, 2016), pp. 82-83. Philippe Couplet and Michael Shen Fuzong's visit to Versailles may even have inspired Maine's commission of the Beauvais tapestry set The life of the emperor of China, Edith A. Standen, 'The story of the emperor of China. A Beauvais tapestry series', Metropolitan Museum Journal, 11 (1976), pp. 103-117.

62 'Qu'on n'estoit pas encore bien informé du detail de tout cela, et qu'il n'appartenoit qu'à un prince comme le Roy de faire venir de ces livres de la China, et des gens pour les traduire', Raissant à Bayle, lettre 540 (my emphasis).

63 'Et l'on m'asseure qu'il est arrivé ces jours cy à Paris jusqu'à 300 volumes de livres Chinois, tant d'histoire civile du pays, que d'histoire naturelle; de mathematique, et d'autres traittez curieux: qu'outre cela il est arrivé aussi deux traducteurs', Raissant à Bayle, lettre 540. On Chinese books in the French Royal Collections: Noël Golvers, Ferdinand Verbiest, S.J. (1623-1688) and the Chinese heaven (Leuven: Leuven University Press, 2003), pp. 204-206.

64 Foss, 'The European sojourn', pp. 125-127. 
people will dedicate themselves unceasingly to translating the most curious of these books, which one will print as soon as they will be in a condition to appear', this never came to pass. ${ }^{65}$

However, as related by Theodore Nicolas Foss, one direct result of Couplet's trip to Paris and his encounter with Louis XIV would be the 'spurring on of France to send qualified missionary-scientists directly to China'. ${ }^{66}$ Ferdinand Verbiest had requested the king of France through a letter delivered by Philippe Couplet for help in the missionary efforts in China. ${ }^{67}$ The aim of this mission was not solely religious, as Louis XIV saw it as a means to increase France's influence, with the added benefit that it would damage the Portuguese monopoly of 'ecclesiastical patronage'.68 The most effective way to achieve this dual goal was to benefit from the scientific interests of the Chinese court. ${ }^{69}$ The activities of the Académie des sciences would thus 'serve as a vehicle for science, God, and France' in the establishment of a French missionary presence in the Middle Kingdom..$^{70}$

Raissant tells of the formation of a group of French missionaries at the close of his letter: 'And as one knows that the Jesuits are agreeable to the king of China, one has sent eight young people to whom the king pays a pension, [to] learn the Chinese language in [that] realm, and to instruct the Chinese literati in the French language and in Latin, so as to make them come to France, to continue their translations and also to teach us their mechanical arts.' ${ }^{71}$ Jean

65 'Que ces gens vont s'appliquer incessamment à traduire les plus curieux de ces livres, qu'on fera imprimer, aussi tost qu'ils seront en estat de paroître', Raissant à Bayle, lettre 540.

66 Foss, 'The European sojourn', p. 130.

67 Mungello, Curious land, pp. 256-257.

68 Mungello, Curious land, p. 329.

69 Isabelle Landry-Deron, 'Les mathématiciens envoyés en Chine par Louis XIV en 1685', Archive for History of Exact Sciences, 55.5 (2001), pp. 423-463.

70 Cathérine Jami, The emperor's new mathematics. Western learning and imperial authority during the Kangxi reign (1662-1722) (Oxford: Oxford University Press, 2011), chapter 5 . After reforms instated in January 1699, the Academy began publishing a volume each year containing reports of the works done by its members, and obituaries for members who had died. Pirated editions of these Histoire et mémoires de l'Académie Royale des Sciences were published in Holland by Pieter Mortier II in 1741. Remarkably, the Dutch editors accused their French colleagues of being at fault, while the Parisian editors accused those of Amsterdam of being incomplete, Roger Hahn, The anatomy of a scientific institution. The Paris Academy of Sciences, 1666-1803 (Berkeley and London: University of California Press, 1971).

71 'Et comme on sçait que les Jesuites sont agreables au roy de la China, on en a envoyé huit jeunes à le Roy paye pension, en son royaume pour apprendre la langue duy pays, et instruire des Chinois spirituels dans la langue François et dans la Latine, afin de les faire venir en France, pour continüe ces traductions et d'autres pour nous apprendre leurs arts mechaniques', Raissant à Bayle, lettre 540. 
de Fontaney was assigned the task to put together a group of suitable young Jesuits. He enlisted Joachim Bouvet, Jean-François Gerbillon, Louis-Daniel Le Comte, Guy Tachard, and Claude de Visdelou, who were all members of the Collège Louis le Grand. These mathématiciens du roy had indeed left France for China the year before. Of the six Jesuits that departed, five would reach Beijing on 7 February 1688 as Guy Tachard remained in Siam. ${ }^{72}$

In the decades following the arrival of the French Jesuits in China, the reports they sent to Europe often found their way to the pages of learned journals and newspapers. Soon, these 'French' accounts on the Middle Kingdom overshadowed information coming from other sources. This not only meant that the printed medium had become 'French', it also had the effect of giving the knowledge distributed about China an increased focus on French sources and subjects. This stance towards France apparently made the erudite journals of the Dutch Republic more suitable for European-wide distribution.

In this process of dissemination, the essential role of the Dutch Republic cannot be underestimated. Especially the province of Holland provided the location where the European Republic of Letters could converge, if not physically, at least in spirit and print. If their publications sold well, it was of lesser concern to Dutch printers, publishers, and booksellers whether this printing transpired in Dutch or French. As such, from the last decades of the seventeenth century onwards, the Dutch-made learned journal was both cause and effect of the growing importance of French as the language of intellectual communication concerning the discussion of China in western Europe.

The imminent publication of the Jesuit translation of Confucius was first announced in the closing paragraph of Pierre Raissant's letter to Pierre Bayle: 'Another letter [I received] imparts that Father Couplet has returned from Rome, where he has made his little Chinese [Michael Shen Fuzong] a Jesuit like himself, and that one hopes that they will translate all the works of Confucius.73 Raissant soon got his wish, for the Nouvelles de la République des lettres reported the publication of Confucius Sinarum philosophus in August 1687: 'New in the month of August 1687:74 Three Dutch journals discussed the Jesuit translation

\footnotetext{
72 An account of his travels was published in Utrecht and Amsterdam in both Dutch and French, Guy Tachard, Reis van Siam, waar in veele tot noch toe onbekende zaaken, zo omtrent de gelegentheid van dit land, als omtrent de religie, zeden, en andere dingen worden verhaald. Gedaan door de vaders Jesuieten (Utrecht: Johannes Ribbius, 1687); Voyage de Siam des peres Jesvites (Amsterdam: Pieter Mortier, 1687).

73 'Une autre lettre porte, que le P. Couplet est revenu de Rome où il a fait son petit Chinois Jesuite comme lui, \& qu'on espére qu'ils traduiront toutes les ouvres de Confutius', Raissant à Bayle, lettre 540.

'Nouveaux du mois d'Août 1687', Nouvelles de la République des lettres (August 1687).
} 
of Confucius: the Histoire des ouvrages des savants, the Bibliothèque universelle et historique, and the reprinted issue of the Journal des sçavans. At first glance these reviews appear implicitly favourable, if only due to the length of the discussion. ${ }^{75}$ However, further analysis demonstrates that the editors of the erudite journals were rather critical, especially about the Jesuit presentation and interpretation of Confucianism.

First of all, however, the transtextual relationship between the reviews and Confucius Sinarum philosophus should be considered. A review is an example of metatextuality, whereby the original content is changed and expanded upon by a third-party discussion. An example of such an expansion is Jean Leclerc's remark in the Bibliothèque universelle et historique that 'in case it [Confucius Sinarum philosophus] be well received in Europe, as there is no reason to doubt: ${ }^{76}$ Such commentaries guide the (potential) perception of the reader beyond the text towards a tendentious opinion (in Leclerc's case, a positive one) of the work discussed.

The reviews are further shaped by the economic rules of cultural consumption to which the editor is either deliberately or unconsciously bound. ${ }^{77}$ In the creation of both form and content, the printer, publisher, and editor had considered the presumed wishes and demands of their customers to make the enterprise of printing a learned journal economically viable. By 1687, a number of journals were available on the European market of print. The commercial appeal of each individual title was thus paramount to any enduring success, which also influenced the creation of content to a certain degree. Notwithstanding the loftier intentions of the journals, they also certainly served as advertisements for their vendors. Books discussed in the Histoire des ouvrages could be 'found in Rotterdam at Reinier Leers', the Nouvelles de la République des lettres promoted Henri Desbordes's stock, and the Bibliothèque universelle and the Journal des Sçavans advertised the wares of a number of Amsterdam printers and publishers such as Abraham Wolfgang and Dirk Boom.

An examination of the Histoire des ouvrages of April 1688 illustrates how the review and sale of books worked in successful commercial tandem. In this issue, Henri Basnage announced the publication of Jean Reuchlin's Dissertation critique sur la nouvelle bibliothèque des auteurs ecclesiastiques. Yet, he only

75 Mungello, Curious land, p. 291.

$7_{6}$ 'Au cas que ceux ci soient bien recus en Europe, comme il n'y a pas lieu d'en douter', Bibliothèque universelle et historique (December 1687), p. 332.

77 Otto Lankhorst, 'Le rôle des libraire-imprimeurs néerlandais dans l'edition des journaux littéraires de langue francais', in Hans Bots (ed.), La diffusion et la lecture des journaux de langue Francaise sous l'ancien régime (Amsterdam and Maarssen: APA Holland University Press, 1988), pp. 1-10. 
reviewed the work in the following edition, as 'we only have been able to read this work in passing, and because Reinier Leers expects copies of it, which he will soon receive, we will give an exact analysis of it next month. ${ }^{78}$ Such a delay between the announcement of the publication of a book and its review meant that the reader had to purchase the next issue if he were to keep up with the latest scholarly information and that the announcement simultaneously functioned as advertisement. This economic factor would have had a considerable impact on the review and discussion of Confucius because it further influenced the transtextual relationship between the reviews and Confucius Sinarum philosophus.

Another factor influencing the reviews and discussion of Confucius is related to the individual role and judgement of the editor, which is visible on two levels. First, these editors expressly spoke to the reader as opposed to merely supplying seemingly objective information. Books were not reviewed anonymously and the voice of the editor was often positioned in dialogue with the readers: 'One leaves it to the reader to judge whether this silence derives from the inexactitude and malice of historians, or whether the zeal of Father Kircher has not made him mistake a supposition for a truth. ${ }^{79}$ Secondly, the opinions of the editors often shone through. While Henri Basnage announced that 'we will strive to speak without any partiality that may shock, or even upset, the other parties', in practice this advocated probity was often flouted in the face of conflicting viewpoints. ${ }^{80}$

It should also be noted that reviewers were simultaneously discussing both content and interpretation of the Jesuit translation of Confucius. Consider the statement that Confucius had known the true God. A reviewer had several options when it came to discussing such possible contentious content. The first would be to simply duplicate the information without commentary, as indeed Journal des sçavans did. This makes the reviewer's statement of the Jesuit interpretation implicitly favourable by withholding explicit judgement.

78 'Mais comme nous n'avons pû lire cét ouvrage qu'en passant, \& que Reinier Leers en attend des exemplaires qu'il recevra au plûtôt, nous remettons à en donner une analyse exacte au mois prochain', Histoire des ouvrages des savants (April 1688), pp. 545-546.

79 'On laisse à juger au lecteur, si ce silence procede ou de l'inexactitude et de la malice de ces historiens, ou si le zele du P. Kircher ne lui a point fait prendre un monument supposé pour un veritable?', Bibliothèque universelle et historique (December 1687), p. 390.

8o 'Nous tacherons de parler sans aucune partialité qui puisse choquer, ni même chagriner les autres partis', Histoire des ouvrages des savants (September 1687); G. van Gemert, 'De Jezuïten in de "Histoire des ouvrages des savants", in Hans Bots (ed.), Henri Basnage de Beauval en de Histoire des ouvrages des savants, 1687-1709. Verkenningen binnen de Republiek der Letteren aan de vooravond van de Verlichting (Amsterdam: Holland Universiteits Pers, 1976), pp. 305-339. 
The second option was to duplicate the statement together with added commentary. This allowed the reviewer to either positively or negatively influence the debate through printed polemic. Such was the approach of the Histoire des ouvrages, which inserted the reviewer's own opinion by referencing a different and somewhat conflicting publication. The third option was to leave out the contentious material altogether. Since most readers would not have had access to Confucius Sinarum philosophus, the reviewer would thereby automatically bypass any possible controversy.

Further analysis of three such types of reviews, from the Journal des sçavans, the Histoire des ouvrages des savants and the Bibliothèque universelle et histori$q u e$, will reveal these distinctions. All three reviews begin with a platitude meant to emphasise the novelty of the information contained within Confucius Sinarum philosophus. At the same time, these proclamations function as a promotional device to the journal in question: 'Even though the author of this philosophy lived more than 500 years before Jesus Christ, we still claim it as a novelty to tickle the curiosity of scholars'. ${ }^{81}$ Each review continues with a general summary of variable lengths, as the foremost function of the learned journals was to inform readers about various subjects. ${ }^{82}$ These summaries not only aided readers in their decision about which books to buy, they also made it possible to become informed about a broad range of subjects without too much effort: 'The journals have been invented for the solace of the readers. Our century dearly loves abbreviated texts, and a certain 'je ne sais quoi' is reigning, which some would call laziness.' 83

Journal des sçavans was generally favourable in its estimation of Confucius Sinarum philosophus. The review described Confucius as a teacher of moral principles that were comparable to Christianity: 'I fail to see how, in regard to the present theme, the charity of the Chinese be different from that of the Christians, so much is it true that God has even spread in the souls of the infidels lights that lead them to virtues which, seen from the outside, are not all that different from Christian virtues.' ${ }^{84}$ The review also emphasised that 'the

81 'Quoy que l'auteur de cette philosophie ait vècu plus de 50o. ans avant Jesus-Christ, nous prétendons pourtant bien en regaler la curiosité des scavans comme d'une nouveauté, Histoire des ouvrages des savants (September 1687), p. 65 (my emphasis).

82 Note that neither editor mentions that Confucius Sinarum philosophus was explicitly dedicated to Louis XIV 'regi Christianissimo'.

83 'Les journaux ont été inventez pour le soulagement des lecteurs: notre siecle aime extremement les abregez, et il regne un je ne sai quoi que quelques uns nommeroient paresse', Histoire des ouvrages des savants (March 1692), pp. 327-328, in Bots, Henri Basnage de Beauval, p. 33.

84 'Je ne vois par qu'au motif près, la charité des Chinois soit différente de celle des chrétiens; tant il est vrai que Dieu a répandu dans l'esprit même des infidèles des lumières qui les 
Chinese have such respect for his [Confucius's] memory, that for more than two thousand years' only his disciples had been accepted into public office. ${ }^{85}$ The general impression of the review is that the Jesuit mission had indeed been successful in China; in the words of David Mungello: 'having a reader (the reviewer) accept their portrayal of the Chinese as very much like Europeans themselves. ${ }^{\prime 6}$ This review demonstrates how the Jesuits at least partially succeeded in presenting Confucius in a favourable light, thereby essentially legitimising their own policy of accommodation.

Henri Basnage de Beauval's review in the Histoire des ouvrages des savants carries a comparably favourable tone. The teachings of Confucius are equated with Christianity, affirming the Jesuit reading of the same: 'It would be rather long to include here all the evidence that the author [Couplet] presents to show that the Chinese have long worshipped the true God'. ${ }^{87}$ Basnage further explained how it was necessary for the Jesuits 'to take off their [priestly] robes to take up those of the literati', thus strengthening the position of the Jesuits even more. He then confirmed their position with the claim that 'nonetheless, they [the Jesuits] might still live ... with all the austerity that their religious habits impose upon them'. ${ }^{88}$ The review also reflected positively on the various Chinese customs of austerity and chastity: 'They lived without splendour and without pomp.... Chastity was honoured there. ${ }^{89}$

However, Henri Basnage proved more critical than his colleague from Journal des sçavans. On the sixth page of the review, Basnage described how 'the Chinese worship the true God under the name Xam Ti'. ${ }^{90}$ He then referred

conduisent à des vertus qui, quant à l'extérieur de l'action, ne sont en rien différentes des vertus chrétiennes', Journal des sçavans (January 1688), p. 176.

85 'Les Chinois ont tant de respect pour sa mémoire, que depuis plus de deux mille ans', Journal des sçavans (January 1688), p. 171.

86 Mungello, Curious land, p. 29o.

87 'Il serait un peu bien long d'insérer icy toutes les preuves que l'auteur rapporte pour montrer que les Chinois ont long-temps adoré le vrai Dieu', Histoire des ouvrages (September 1687), pp. 65-79.

88 'Il étoit necessaire de quitter leur habit pour prendre celui des Lettrez ... il pourraient cependant vivre avec toute l'austérité que leur imposait leur habit de Religieux', Histoire des ouvrages (September 1687), p. 68.

89 'Ils vivaient sans fast et sans pompe ... La chasteté y était honorée', Histoire des ouvrages (September 1687), p. 7 o.

$90 \quad$ 'Les Chinois adoraient le vrai Dieu sous le nom Xam Ti', Histoire des ouvrages (September 1687), p. 7o. Matteo Ricci first applied the Chinese concept of Shangdi 上帝 (the sovereign on high) to the Christian conception of God. Ricci believed that several mentions of Shangdi in the Five classics and Lunyu proved that the Chinese had gained a true knowledge of God. According to Ricci, this knowledge had disappeared in China due to the introduction of Buddhism, Meynard, The Jesuit reading of Confucius, p. 8. 
to a passage found in chapter ten of the first part of Confucius Sinarum philosophus, which related how the early Christians preached the word of God to the Romans and Greeks: 'It was the very name Deus, the friars say. But for the pagans of those ancient times, could this word have meant something else than a god similar to Saturn, Jupiter, or Mercury?'91 Basnage offered his own contribution to the debate by suggesting that 'perhaps Father Couplet has not taken notice, that one will also have been able to preach the true God, and worship him, under the name of Jupiter, because according to the most skilled pagans, Jupiter the master of heaven and the ruler of Gods, was Neptune at sea, Mars in combat, Pluto in the underworld; and this was nothing other than a single God called by his different names, which served no other purpose than to express his different qualities. ${ }^{92}$

This statement by Basnage stands in direct transtextual relationship with Gijsbrecht Cuper's 1676 book on the Egyptian deity Harpocrates. In this booklet, the Dutch historian and politician Cuper described an object from the collection of Johannes Smetius that depicted the Egyptian god, Harpocrates. ${ }^{93}$ Cuper related how the object itself was of Roman origin but that the interpretation of Harpocrates harked back to ancient Egypt and Greece. ${ }^{94}$ Consequently, different cultures had given different names to this deity, while still referring to the same god. Basnage may have been referencing Cuper in this context, as the latter's statements on Harpocrates echoed those of the Jesuits regarding Confucius. Furthermore, Basnage surely wished to make a friend of Cuper by referring to him as an authoritative source. As an influential member of the Republic of Letters, Cuper's endorsement of the Histoire des ouvrages could be beneficial to Henri Basnage's commercial enterprise. ${ }^{95}$ To ensure that Cuper indeed saw the reference to his own book, Basnage sent him a copy: 'You will

91 Meynard, Confucius Sinarum philosophus, p. 214.

92 'Mais le P. Couplet n'a peut-être pas pris garde, que l'on aurait pu aussi prêcher le vrai Dieu et l'adorer sous le nom de Jupiter, car selon les plus habiles Payens, Jupiter le maître du ciel et le souverain des Dieux, était Neptune sur la mer, Mars dans les combats, Pluton dans les enfers; et ce n'était qu'un seul Dieu exprimé sous ces different noms, qui ne servaient qu'à exprimer ses différentes qualitez', Histoire des ouvrages (September 1687), pp. 70-71.

93 Gijsbrecht Cuper, Harpocrates seu explicatio imaguncula argentece antiquissimce, sub Harpocratis figura ex Agyptiorum instituto solem reprcesentantis (Amsterdam: Theodorus Pluymer, 1676); Harold Cook, Assessing the truth. Correspondence and information at the end of the Golden Age (Leiden: Primavera Press, 2013), pp. 25-26.

94 Michel Malaise, À la découverte d'Harpocrate à travers son historiographie (Brussels: Académie Royale de Belgique, 2011).

95 Bianca Chen, 'Digging for antiquities with diplomats. Gijsbrecht Cuper (1644-1716) and his social capital', Republics of Letters. A Journal for the Study of Knowledge, Politics and the Arts, 1 (2008). 
no doubt find that I take a little too much liberty in presenting you with the first attempt of my journal ... I would be delighted if you would find some time to let it occupy you for a few moments, but you are too knowledgeable and too skilled, sir, [for me to] flatter myself that my fault could escape all your [critical] light'. ${ }^{96}$ Evidently, Basnage's flattery bore fruit. A letter signed on 22 November 1688 tells us that Cuper was nothing but complimentary of Basnage's journalistic efforts, 'which you [Basagne] work at with so much success, and to much praise ... and I am persuaded that the savants will be well at ease to be able to know its merits. ${ }^{97}$

The longest and most comprehensive review of Confucius Sinarum philosophus appeared in the Bibliothèque universelle et historique. Its 69 pages contained extensive translations in French of passages taken from each of the three Confucian books. The sheer length of this treatment seems to mark the review as favourable, which is further emphasised by statements such as 'there is no reason to doubt that these [will] be well received in Europe. ${ }^{98}$ However, David Mungello has argued that Jean Leclerc (the reviewer) was quite critical in his discussion. ${ }^{99}$ Most of this criticism centred around the Jesuits' contention that the Chinese, both common and learned, revered Confucius as they did their deceased ancestors. This statement made a distinction between civil and religious honours, a concept which stood at the heart of the Jesuit policy of accommodation. The Jesuits felt that it was important to 'accommodate' Chinese ritual practices to facilitate Chinese conversion to Christianity. This was rooted in the Jesuit belief that Chinese ritual practises were not based on any notion that the souls of ancestors existed after death or that Confucius was a god. Yet, as already indicated by Leclerc's review, the debate concerning the religiosity of the teachings of Confucius would soon become one of the primary points of contention in the Chinese Rites Controversy. There were three

96 'Vous trouverez sans doute que ie prens un peu trop de liberté de vous presenter le premier essai de mon iournal ... je serois ravi que vous y trouvassiez de quoi vous occuper quelques momens, mais vous estes trop scavant et trop habile, monsieur, pour me flatter que mes defauts puissent echaper à toutes vos lumieres', Basnage à Cuper, [September 1987], in Hans Bots and Lenie van Lieshout, Henri Basnage de Beauval et sa correspondance à propos de l'Histoire des ouvrages des savants (Amsterdam and Maarssen: APA Holland University Press, 1984), Lettre 1, p. 1.

97 'À qui vous travaillez avec tant de succes, et aec tant de louange ... et je suis persuadé que les scavans seront bien aises e'en pouvoir connoistre les merites', Cuper à Basnage, 22 November 1688, in Bots and Van Lieshout, Henri Basnage de Beauval et sa correspondance, Lettre 4, p. 4 .

98 'Il n'ya a pas lieu d'en douter ... que ceux ci soient bien recus en Europe', Bibliothèque universelle et historique (December 1687 [1688]), p. 322.

99 Mungello, Curious land, p. 291. 
main issues at the heart of this controversy. Catholic powers in Rome and Paris felt that the ceremonies held in honour of Confucius went against Christian doctrine; together with the special honours paid to ancestors, modes of tribute and filial piety; and the semantic search for the appropriate Chinese terms to refer to the Christian God.

In his review, Leclerc referred to this dispute by stating that 'the revered Jesuit fathers will have a great deal of trouble persuading the Europeans that the excessive veneration of this philosopher by the Chinese be nothing else than purely [driven by] civil respect, and that one does not grant him divine honours'.100 Here, the review is in direct metatextual dialogue with Confucius Sinarum philosophus. Leclerc notes that Philippe Couplet spoke of the 'excessive honour' with which the ancient Chinese venerated their forefathers. ${ }^{101}$ However, according to this review, this sort of reverence is difficult to justify, as Couplet himself admitted that 'the respect that the ancient Chinese had for their ancestors has in recent times degenerated into superstition among the moderns.' 102

Leclerc also discussed the Jesuit interpretation of the Chinese concept Xam Ti, or Shangdi, a subject which would have been familiar to readers of Basnage's the Histoire des ouvrages. Yet, while Basnage was still somewhat circumspect in his judgement, Leclerc was perfectly blunt in stating that Couplet 'takes a long time to prove that [the Chinese] understand nothing else by T'ien than the true God'. However, he does not believe himself obliged to report his reasons, 'since there is nothing more ordinary in all languages than giving the name of Heaven to the Divinity'.103 Here, it seems that Leclerc is more critical of the manner which the information is presented, and by whom, than by its philosophical or religious consequences.

Leclerc finished his review by remarking upon Athanasius Kircher's China illustrata in a less than flattering manner. He questioned whether Kircher's report of the discovery of the Nestorian Stele in 1625 was truthful, noting how Chinese historians do not mention this discovery: 'Is it not surprising that the

100 'Les R.R.P.P. Jésuites auront beaucoup de peine à persuader aux Européens que la veneration excessive des Chinois, pour ce philosophe, ne soit qu'en respect purement civil, et qu'on ne lui tende pas les honneurs divins', Bibliothèque universelle (December 1687), p. 344 (my emphasis).

101 Couplet, Confucius Sinarum philosophus, p. 84, from Mungello, Curious land, p. 291.

102 'Le respect que les anciens Chinois avoient pour leurs ancêtres est dégénéré en superstition parmi les modernes', Bibliothèque universelle (December 1687), p. 344 (my emphasis).

103 'S'arrête longtemps à prouver qu'ils n'entendaient autre chose par Tien que le vrai Dieu', 'puit qu'il n'est rien de plus ordinaire dans toutes les langues donner le nom de ciel à la divinité, Bibliothèque universelle (December 1687), p. 389. 
Chinese historians, who extensively report of that time, do not say a word of so great an event?'104 How Leclerc would have known what Chinese historians did or did not report remains unclear. Not content with this analytical blow, the review continued to rub salt in the wound of Couplet's translation by claiming that the Tabula chronologica only described a small selection of China's history. According to Mungello, 'coming on the heels of Leclerc's criticism of Kircher for fabrication, the implied criticism was that Couplet had distorted the picture of Chinese history through a calculated selection' ${ }^{105}$

Confucius Sinarum philosophus closed with a Tabula chronologica monarchiae Sinicae ('Chronological table of Chinese monarchy'). This compendium was produced by Philippe Couplet and ranged across Chinese history from $2952 \mathrm{BCE}$ until Couplet's departure from China in 1683 . As befitting its Jesuit inception, the table is divided into two sections: ante Christum and post Christum. A Tabula genealogica trium familiarum imperialum monarchiae Sinicae ('Genealogical table of three imperial households of the Chinese monarchy'), and a map of China with the inscription Imperii Sinarum et rerum in eo notabilium sinopsis ('Summary of the Chinese Empire and of notable things there'), are usually bound between the two sections of the Tabula chronologica. ${ }^{106}$

According to Mungello, this chronological table 'was one of the most significant works published on China in seventeenth-century Europe.'107 Accurate chronologies were cause for great concern for early modern European historians, and the antiquity of China figured heavily in these discussions. After the Gregorian calendar reforms of 1582, European scholars used the Bible as the major reference in establishing a chronology of the world, recalculating the year of the Creation and the Deluge. ${ }^{108}$ By the seventeenth century, two chronologies were leading; one, based on the Vulgate (the Latin translation

104 'N'est il pas étonnant que les historiens Chinois, qui rapportent jusqu'aux minucies de ce temps-là, ne disent pas un mot d'un si grand évenement?', Bibliothèque universelle (December 1687), p. 389 .

105 Mungello, Curious land, p. 292.

106 Marcia Reed and Paola Demattè (eds.), China on paper. European and Chinese works from the late sixteenth to the early nineteenth century (Los Angeles: Getty Research Institute, 2011), pp. 172-173.

107 David E. Mungello, 'A study of the prefaces to Ph. Couplet's Tabula chronologica monarchiae Sinicae', in Malek (ed.), Philippe Couplet, pp. 183-199, p. 183.

108 Standaert, The intercultural weaving, p. 156. 
of the Hebrew Bible made around $400 \mathrm{CE}$ ), was the most commonly accepted by the Catholic Church. This chronology placed the creation of the world at 23 October 4004 BCE, and the Flood in 2348 вCE. Calvinist and Dutchman Isaac Vossius, was responsible for another chronology based on the Septuagint. This was a much earlier Greek translation of the Hebrew Bible, made in the third and second centuries CE. The Septuagint placed the creation of the world in 5622 в $\mathrm{CE}$, and the Deluge 2256 years later in 3366 вСЕ.

The main problem with these chronologies was that Martino Martini had claimed in his Sinicae historiae decas prima (1658) that the records of Chinese history were older than those known in Europe. ${ }^{109} \mathrm{He}$ stated that Chinese records went back more than 600 years before the time of the Deluge, and that outer parts of Asia were certainly inhabited prior to this event. ${ }^{110}$ From this premise followed the problem of how to reconcile China's history with biblical authority. It would be impossible to explain the existence of Chinese records predating the 'universal' Flood, if one held that the entire human race, with the exclusion of Noah and his family, had drowned. ${ }^{111}$ Such a contradiction could have far-reaching consequences. If the world was to be declared much older on account of China's antiquity, the universal history of the Bible would no longer be valid. Additionally, this revised chronology would reduce biblical events such as the construction and fall of the Tower of Babel to mere local events, 'involving a minor people in a circumscribed region of the world."12

Jean Leclerc's review identified the problem that 'according to this same calculation, the Chinese Empire will be older than the Deluge.'13 His journal was not the only one to pay an inordinate amount of attention to the subject of China and the problem of biblical chronology. The Histoire des ouvrages also gave a thorough exposition: 'What bothers the author [Couplet] is that one

109 Han Qi, 'The Jesuits and their study of Chinese astronomy and chronology in the seventeenth and eighteenth centuries', in Luís Saraiva (ed.), Europe and China. Science and the arts in the 17th and 18th centuries (London and Hackensack: World Scientific Publishing, 2012), pp. 71-79, p. 72.

110 Anthony Grafton, 'Dating history. The Renaissance \& the Reformation of chronology', Daedalus, 132.2 (2003), pp. $75^{-85}$, p. 84.

111 William Poole, 'The Genesis narrative in the circle of Robert Hooke and Francis Lodwick', in Ariel Hessayon and Nicholas Keene (eds.), Scripture and scholarship in early modern England (London: Routledge, 2017), chapter 2.

112 Paolo Rossi, The dark abyss of time. The history of the earth and the history of nations (Chicago and London: The University of Chicago Press, 1984), p. 140.

113 'Mais selon ce calcul même, l'Empire des Chinois serait plus ancien que le Deluge', Bibliothèque universelle (December 1687), p. 368. 
does not find any evidence of the Flood.'114 This sentiment is echoed in Journal des sçavans, 'which seems to oblige [us] to order the antiquity of time after the computation of the Septuagint, rather than following the Hebrews, because these have so whittled down the age of the world since its creation that, if their chronology were true, the beginning of the Chinese monarchy would stretch back about 66o years beyond the Deluge, as it appears by this calculation'.115

The primary aim of most learned journals was to provide readers with 'unbiased' information, yet some opinions do peek through their respective discussions of the problems concerning China's antiquity. Journal des sçavans generally followed the lead of the Jesuits, yet the Histoire des ouvrages did not draw the same conclusion: "There is no evidence of the Flood, but he [Couplet] claims that an imperfect solution could be found in their [the Chinese] opinion that the whole world was once covered by water'.116 The review thereby refers to Couplet's preface to Tabula chronologica, in which he broached the subject of the Great Flood.

Surprisingly, Couplet never offered any real solution to the problem. He found nothing 'certain or firmly established in the books and monuments of the Chinese' on the subject of any universale diluvium. Yet, he noted that it may be possible to find evidence of a 'deluge' in the Xingli dachuan, or 'Great compendium of natural and moral philosophy': an official anthology of neo-Confucian thought, compiled by the Yongle Emperor 永樂 (1402-1424). This work was primarily assembled by neo-Confucian philosophers of the Song dynasty, such as Zhu Xi 朱喜 (1130-1200). ${ }^{117}$ Couplet's notion that the riddle of the Flood could be solved through neo-Confucian works seems

114 'Ce qui embarrasse l'auteur est que l'on n'y trouve aucune preuve du Déluge', Histoire des ouvrages (September 1687), pp. 65-79.

115 'Ce qui semble obliger à régler l'antiquité des temps suivant la supputation des Septante, plutôt que suivant celle des Hébreux; parce que ceux-ci ont tellement resserré la durée du monde depuis sa création, que si leur chronologie était véritable, le commencement de la monarchie de la Chine se trouverait environ 66o ans au delà du Déluge, comme il paraît par ce calcul', Journal des sçavans (January 1688), pp. 167-180.

116 'Ce qui embarrasse l'Auteur est que l'on n'y trouve aucune preuve du Déluge: mais il prétend que l'on peut en trouve une idée imparfaite dans l'opinion qu'ils ont, que tout cet Univers n'étant d'abord composé que d'eau', Histoire des ouvrages (September 1687), pp. $65^{-79}$.

117 In general, neo-Confucianism was rejected by the Jesuits. They believed that this philosophy, which originated with Han Yu 韓愈 and Li Ao 李垍 (772-841) in the Tang Dynasty (618-907) and became prominent during the Song and Ming dynasties, had corrupted and distorted the teachings of the ancient philosophers Confucius and Mencius: Knud Lundbaek, 'The image of neo-Confucianism in Confucius Sinarum philosophus',Journal of the History of Ideas, 44.1 (1983), pp. 19-30. 
mere speculation. ${ }^{118}$ Nonetheless, it led the Jesuit to declare that the Chinese believed that the world was once covered by water 'and that is why one finds shells on top of the highest mountain.'119

The Bibliothèque universelle is even more circumspect in its description of the Tabula chronologica. In the first part of the review, the reader is provided with both options: 'To follow the calculation of the Septuagint', and 'if we want to stick to the computations of the Hebrews.'120 Yet, the author soon acknowledged how 'according to this same calculation, the Chinese Empire will be older than the Deluge', but without giving any explanation of this rather contentious piece of information. ${ }^{121}$ Over the next 6o pages, the reviewer extensively used information taken from Tabula and its preface, yet without referring again to the problematic implications of this information. Finally, on one of the last pages, the author returned more explicitly to the Tabula, simply stating that 'we shall not dwell a long time on the third part of this collection, which is a chronological table of the kings of China, because we have already taken several things from it, to make the summary we have given of the religion and antiquities of the Chinese Empire.'.122

For a long time, Europeans had been concerned with the problems of biblical chronology, and the publication of Confucius Sinarum philosophus added fuel to an already blazing fire. ${ }^{123}$ During the late sixteenth century, Protestant Joseph Scaliger was Europe's greatest expert on chronology and its connection to biblical authority. He expanded the notion of classical history from Greek and Roman antiquity to include Persian, Babylonian, Jewish, and ancient Egyptian history. ${ }^{124}$ In the last 16 years of his life, from 1593 until 16og, Scaliger

\footnotetext{
118 Mungello, 'A study of the prefaces', p. 193.

119 'Et que c'est pourquoi l'on trouve des coqilles sur les plus haut montagnes', Histoire des ouvrages des savants (September 1687), p. 77; Couplet, Confucius Sinarum philosophus, p. vi.

120 'A suivre le calcul des Septante', and 'si l'on veut s'en tenir à la supputation des Hébreux', Bibliothèque universelle (December 1687), p. 333.

121 'Mais selon ce calcul même, l'Empire des Chinois serait plus ancien que le Deluge', Bibliothèque universelle (December 1687), p. 333.

122 'On ne s'arrêtera pas long-temps sur la troisieme partie de ce recueil, qui est une table chronologique des rois de la Chine; parce qu'on en a déja tiré plusieurs choses, pour faire l'abbregé qu'on a donné de la religion et des antiquitez de l'empire Chinois', Bibliothèque universelle (December 1687), p. 388.

123 On the Jesuit discussion of China's antiquity see Standaert, The intercultural weaving, pp. 94-115.

124 Anthony Grafton, Joseph Scaliger. A study in the history of classical scholarship (Oxford: Clarendon Press, 1994).
} 
lived and worked in the Dutch Republic, and it was there that the subsequent discussion on the subject of chronology predominantly took place.

The half-century after Scaliger's death saw many contributors to the debate, many of whom were Protestants, indicating that polemics concerning China was not always motivated by a difference in religion. One curious example is that of French Huguenot theologian Isaac La Peyrère, who argued in 1655 that man had lived before Adam, thus conveniently solving many problems related to chronology. ${ }^{125}$ When the Amsterdam printing firm Elzevier issued three different editions of La Peyrère's exposition in the same year, complaints soon started rolling in, and the book was banned on the grounds that it contained 'some horrible and blasphemous opinions contravening God's Holy Word'.126

The discussion did not end there and, from 1659 onwards, the Dutchman Isaac Vossius stood at the eye of 'the storm over chronology'.127 Vossius, son of esteemed humanist Gerhard Vossius, was a Calvinist philologist, well known for his excellent library of books and manuscripts. ${ }^{128}$ As a scholar, he had long been preoccupied with China, from which followed a fascination with the antiquity of the world. ${ }^{129}$ His pamphlet Dissertatio de vera aetate mundi of 1659 argued that the universe was 1440 years older 'than is usually calculated.' ${ }^{130}$ Using the chronology of the Septuagint (the Greek version of the Old Testament) instead of the Hebrew Masoretic text, Vossius claimed that the date of creation should be placed at about 5400 вСE. In lengthening the history of the world by 1440 years, Vossius reconciled conflicting Chinese and biblical evidence. ${ }^{131}$ From the

125 Isaac de La Peyrère, Prce-adamitce. Sive exercitatio super versibus duodecimo, decimotertio, \& decimoquarto, capitis quinti epistolce D. Pauli ad Romanos (Amsterdam: Daniel and Lowijs Elzevier, 1655); Eric Jorink, “Horrible and blasphemous”. Isaac La Peyrère, Isaac Vossius and the emergence of radical biblical criticism in the Dutch Republic', in Jitse van der Meer and Scott mandelbrote (eds.), Nature and scripture in the Abrahamic religions: up to 1700 (vol. 1, Leiden and Boston: Brill, 2008), pp. 439-46o.

126 National Archives of the Netherlands, The Hague, Missiven van het Hof van Holland, 1oe register, nr. 39o, fol. 206, via Eric Jorink, Reading the book of nature, in the Dutch Golden Age, 1575-1715 (Leiden and Boston: Brill 2010). p. 64.

127 Anthony Grafton, 'Isaac Vossius, chronologer', in Jorink and Van Miert (eds.), Isaac Vossius (1618-1689), pp. 43-84, p. 43.

128 After his death in 1689, his heirs sold the collection to Leiden University, where it is still kept as the Codices Vossiani, containing 4000 rare manuscripts and books, see Codices Vossiani Latini Online, https://brill.com/view/db/cvlo, last accessed 23 August 2021.

129 Weststeijn, 'Vossius' Chinese utopia', pp. 207-242.

130 'Dat men gemeenlijck reeckent'. Isaac Vossius, Discours van de rechten ouderdom der wereldt. Waer in getoondt wordt dat de werelt ten minsten 1440 jaren ouder is, dan men gemeenlijck reeckent (Amsterdam: Tymon Houthaeck and Jan Hendricksz Boom, 166o), title page.

131 Jorink, Reading the book of nature. 
very first pages, Vossius raised the problem of the antiquity of other cultures such as 'the Babylonians and Egyptians. Added to these are the Chinese. ${ }^{132} \mathrm{He}$ further expounded on this reasoning in De septuaginta interpretibus eorumque translatione of 1661, arguing that the Greek version of the Bible was preferable in the process of calculating time. Conveniently, his new chronology gave a satisfactory explanation for the antiquity of many civilisations: among them, the Chinese. ${ }^{133}$

Adriaen Vlacq of The Hague first published Vossius's Dissertatio de vera aetate mundi. ${ }^{34}$ Tymon Houthaeck and Jan Hendricksz. Boom of Amsterdam translated the work into Dutch within the year. This Dutch edition begins with a letter from 'the translator to his friend Mr. Leonard Pot'.135 This preface is interesting because it testifies to the intentions of the rest of the book, while at the same time explaining why a translation into Dutch was deemed necessary. The writer first clarifies why he did not publish this translation earlier: 'The cause for this is, that I first wanted to see what learned men thought of it, and how the writer would defend his feelings; this, I think, having been done well, the translation appears forthwith.'.136 This statement referred to the overwhelming amount of criticism that befell Vossius after the publication of his chronology. While some may have found in Vossius's theory an answer to the long-standing question of Chinese chronology, his De vera aetate queried established views and he soon became involved in a heated polemic.

Vossius's main opponent was German historian, Harderwijk professor and pious Calvinist, Georg Hornius. Hornius tried to refute Vossius's chronology in several pamphlets as well as in his book, Arca Noae, published in 1666.137 Hornius first responded to the notion that the Flood was not universal but limited to Palestine. In the preface, Hornius presents Vossius as a secret follower of the pre-Adamite doctrine of La Peyrère. According to Hornius, this belief

132 'De verdediginge van hun gevoelen zoecken sy in de outheydt van de Babyloniers en Egyptenaren. By deze voegen eenige de ... Sinesen', in Vossius, Discours van de rechten ouderom der wereldt, p. 28.

133 Isaac Vossius, De Septuaginta interpretibus, eorumque translatione \& chronologia dissertationes (The Hague: Adriaen Vlacq, 1661).

134 Isaac Vossius, Dissertatio de vera aetate mundi (The Hague: Adriaen Vlacq, 1659).

135 Vossius, Discours van de rechten ouderom der wereldt, fl. *2.

136 'Daer van is dit de oorzaecke, dat ick eerst wilde zien wat geleerde luyden daer van oordeelden, en hoe den Schrijver sijn gevoelen verdedigen zoude; dit, mijns bedunckens, wel geschiedt zijnde, zo komt de overzettinge nu mede te voorschijn', in Vossius, Discours van de rechten ouderdom der wereldt, p. 132.

Weststeijn, "'Vossius" Chinese utopia', pp. 208-210. 
would 'lead straight to atheism', and had already been refuted. ${ }^{138}$ The only course of action Hornius saw as appropriate was 'that folly [be] struck by the strongest of arguments, so that, scarcely born, that unhealthy opinion, which was supported by no proof, was snuffed out. If any of its followers remain, may they be punished with scorn or with magistrates' sentences'.139

Both Vossius and Hornius believed that the world was created by God, yet Hornius drew a different conclusion from this premise than Vossius. Hornius reasoned that, if the world was created by God, the true beginning should be sought with Moses. And this book of Moses may exist in different languages, but Hebrew is the true and original language in which the Bible was written, all others are translations. Hornius then went on to undermine arguments made by Vossius, and several chapters are devoted to the antiquity of the Egyptians, Chaldeans, Arabs and Chinese. ${ }^{140}$ Hornius provided arguments to align the antiquity of these cultures in accordance with traditional chronology. According to him, every chronology that differed from the Mosaic tradition was 'fabulous', expressing merely the desire found in every people for 'prolonging its own history' and of 'declaring its own origins to be very distant and, hence, more noble.'141

Vossius swiftly responded to Hornius with a pamphlet entitled Castigationes ad scriptum G. Hornii de aetate mundi (1659). In this work, he not only discussed the Septuagint in relation to the Hebrew Bible, but also delved deeper into the questions of chronology. Concerning the Chinese, Vossius accused Hornius of confusing Cathay and China: an error which should have been laid to rest decades earlier. ${ }^{142}$ Vossius also claimed that Hornius clearly understood nothing of Martino Martini's work, and had written only nonsense about it. In the same year of 1659, Hornius replied in yet another pamphlet that Vossius had no right to use Martini as an argument concerning Chinese chronology since the Jesuit had limited himself to repeating what the Chinese believed to be true, but he does not by any means approve of their opinions.' ${ }^{143}$ Hornius's arguments

138 Georg Hornius, Arca Noae: sive historia imperiorum et renorum a conditio orbe ad nostra tempora (Leiden and Rotterdam: Petrus Hackius, Cornelius Hackius and Jacobus Hackius, 1666), praefatio ad lectorem.

139 Georg Hornius, Dissertatio de vera aetate mundiqua sententia illorum refellitur qui statuunt natale mundi tempus annis minimum 1440 vulgarem aeram anticipare (Leiden: Johannes Elzevier, 1659), fl. 2.

140 Weststeijn, 'Spinoza Sinicus', pp. 537-561.

141 Hornius, Dissertatio de vera aetate mundi, pp. 1-3.

142 Djoeke van Netten, 'The richest country in the world. Dutch knowledge of China and Cathay and how to get there in the 159os', in Thijs Weststeijn (ed.), Entangled cultural histories. Encounters between China and Europe, 1590-1800 (Leiden: Brill, 2020), pp. 24-56.

143 Hornius, Defensio dissertationis, p. 5o, p. 54. 
against Martini revolved around the idea that latter had never believed in Chinese history and chronology, and that 'he laughed at it'. Of course, Martini, still residing in China, could never have said so 'without most grave danger.'144 In another swift reply, Vossius exclaimed that 'you say that Martini thought in one way and wrote in another. Marvellous among mortals, you know what Father Martini thought better than he did himself!' However, Martini's work was available to all so readers could see for themselves that Martini's history of China 'takes place over 4600 years: sure, constant and uninterrupted.'145

Concerning Martini's works and his own, Vossius was certainly right about their widespread availability. Martini's first work on the Manchu Conquest of 1644 was translated in Dutch, English, German, French, Italian, Portuguese, Spanish, Swedish, and Danish before the end of the century and it was reprinted 20 times before $1706 .{ }^{146}$ Admittedly, Martini's work on Chinese history and chronology (from which Vossius took the argumentation) was less widely distributed, as editions were limited to two in Latin, printed in Munich and Amsterdam. ${ }^{147}$ However, Isaac Vossius's work about the antiquity of China was translated into Dutch, unlike any of Hornius's books on the same subject. Scholars had a wider array of works to choose from if they wanted to inform themselves on the subject of biblical chronology. People who could not read Latin, still the greater part of the Dutch population, had to make do with Vossius's account. ${ }^{148}$ Yet, those people versed in French were also enlightened by the learned journals. ${ }^{149}$

The debate surrounding the incompatibility of China's antiquity with the chronology of the Bible was not the only controversy surrounding Europe's introduction to Confucius Sinarum philosophus. Soon, a group of radical thinkers would use the polemic possibilities of Confucius to their own advantage. The Protestant polemic between Vossius and Hornius demonstrates how the former deployed China's antiquity and the venerable character of Confucianism to argue that the Greek text of the Bible was more reliable than the Hebrew

\footnotetext{
144 Hornius, Defensio dissertationis, p. 54.

145 Vossius, auctarium castigationum, pp. 40-41.

146 Martini, De bello Tartarico historia; Van Kley, 'Qing dynasty China in seventeenth-century Dutch literature', pp. 219-220.

147 Martino Martini, Sinicce historice decas prima. Res a gentis origine ad Christum natum in extrema Asia, sive magno Sinarum imperio gestas complexa (Munich: Johannes Wagner Civis, 1658; Amsterdam: Johan Blaeu, 1656).

148 On the culture of translating in early modern Europe, see Hosington, 'Translation and print culture in early modern Europe', pp. 5-18.

149 Brown, 'History and the learned journal', pp. 365-378.
} 
one. ${ }^{150}$ Chinese society could not be praised high enough, according to Vossius, and he claimed that the Middle Kingdom was not only the oldest but also the most praiseworthy of all civilisations. ${ }^{151}$ Vossius was not the only proponent of this highly appreciative 'philosophical Sinophilia.'.152 In his commendation of the Middle Kingdom, he was joined by the English statesman and essayist William Temple and the seigneur de Saint-Évremond, Charles de Marguetel. Incidentally, all three lived and worked in The Hague during the late 166 os. $^{153}$ According to Temple, Confucius was 'the most learned, wise and virtuous of all the Chinese', and his opinion that there would be no better model for men to emulate was shared by Vossius and Saint-Évremond. ${ }^{154}$

Even though this philosophical Sinophilia was only propagated by a relatively small number of thinkers, its explanation of Confucianism as a moral and political order that could potentially serve as a model for all mankind proved influential. Especially the French thinkers Henri de Boulainvilliers, Simon Tyssot de Patot, Jean-Jacques Dortous de Mairan, Antoine-Augustin Bruzen de La Martinière, Jean-Baptiste Boyer, Marquis d'Argens, and the Italian-born Alberto Radicati would take up the cause of Confucius in the eighteenth century. ${ }^{155}$ While bearing many similarities, the Sinophilia of Vossius, Temple and Saint-Évremond on the one side and that of the French thinkers of the early eighteenth century on the other, is divided by the mountain of knowledge that is Confucius Sinarum philosophus. The publication of the Jesuit translation of Confucius truly marks the moment at which China became philosophically interesting to European thinkers, as so much more substantive and polemic information became available. ${ }^{156}$ With the Confucius Sinarum philosophus, the Jesuits aimed to prove that the teachings of Confucius, and by implication those who adhered to them, were not in conflict with Christianity. However, Couplet's explanation of Confucianism caused the greatest controversy, not

150 Richard H. Popkin, 'The crisis of polytheism and the answers of Vossius, Cudworth, and Newton', in James E. Force and Richard H. Popkin (eds.), Essays on the context, nature, and influence of Isaac Newton's theology (Dordrecht: Springer, 199o), pp. 9-25.

151 Scott Mandelbrote, 'Isaac Vossius and the Septuagint', in Jorink and Van Miert, Isaac Vossius (1618-1689), pp. 56-57.

$15^{2}$ Israel, Enlightenment contested, p. 641.

153 David S. Katz, 'Isaac Vossius and the English biblical critics', in Richard H. Popkin and Arjo J. Vanderjagt (eds.), Scepticism and irreligion in the seventeenth and eighteenth centuries (Leiden, New York and Köln: Brill, 1993), pp. 142-184.

154 Samuel H. Monk (eds.), Five miscellaneous essays by Sir William Temple (Ann Arbor: University of Michigan Press, 1963), p. 113; Israel, Enlightenment contested, p. 641.

155 Pinot, La Chine et la formation, pp. 151-152.

${ }_{15} 6$ Yuen-Ting Lai, 'The linking of Spinoza to Chinese thought by Bayle and Malebranche', Journal of the History of Philosophy, 23.2 (1985), pp. 151-178. 
only within the Society of Jesus itself, but also within a broad group of European thinkers.

\section{$4 \quad$ Critiquing Confucius}

French Jansenist Antoine Arnauld was one of the first in Europe to formulate a clear critique of Confucius as presented by the Jesuits. ${ }^{157}$ Arnauld averred that the Confucian philosophy practised by the Chinese emperor sounded, even in its Jesuit telling, much like atheism: 'These nations, which profess no religion, appear incapable of the most common reasoning that leads other men to the true or false knowledge of a divinity'.158 According to Arnauld, Ricci had proposed that the Chinese character for mere 'material sky' was translated as 'true God' (天 Tian). Nicolò Longobardo had already refuted this meaning, but never spoke out about it. Yet, Arnauld declared that since the time of Ricci, many missionaries (mainly Dominicans and Franciscans) had demonstrated that Chinese philosophers were only materialistic, meaning that they did not distinguish between spiritual substance and mere matter. The Chinese literati therefore could have no correct notion 'neither of God, the angels, nor our soul.' ${ }^{159}$ Arnauld's critique of China was mainly aimed at the Jesuit interpretation of Confucianism since, according to him, they had known the Chinese to be atheistic, but tried to hide that fact from the European public.

157 On Jansenism and its Jesuit opposition see William Doyle, Jansenism. Catholic resistance to authority from the Reformation to the French Revolution (New York: St. Martin's Press, 200o); Dale van Kley, 'The rejuvenation and rejection of Jansenism in history and historiography. Recent literature on eighteenth-century Jansenism in French', French Historical Studies, 29.4 (2006), pp. 649-684; Jeffrey D. Burson, 'Between power and enlightenment. The cultural and intellectual context for the Jesuit suppression in France', in Jeffrey D. Burson and Jonathan Wright (eds.), The Jesuit suppression in global context (New York: Cambridge University Press, 2015), pp. 40-64. Between 1654 and 1756, 121 of Arnauld's works were published in the Dutch Republic.

158 Antoine Arnauld, Oeuvres de messire Antoine Arnauld, vol. 34, Morale pratique des Jésuites (Paris and Lausanne: Sigismond D'Arnay, 1780), chapter 11; David Jones, The image of China in Western social and political thought (Hampshire and New York: Palgrave, 2001), pp. 17-20. The different parts of Morale pratique des Jésuites were published in 1692 and 1693 under the respective titles of Histoire des différens que les missionnaires Jésuites d'une part, \& ceux des Ordres de S. Dominique \& de S. François de l'autre, ont touchant les cultes ques les Chinois rendent à leur maître Confucius, 1692; Suite de l'histoire des différens entre les Jésuites de la Chine d'une part \& des missionnaires des Ordres de St. Dominique et de St. François de l'autre, 1693 . Neither book has a place nor name of publication stated, but it is highly likely they were in fact printed in Amsterdam.

'Ni de Dieu, ni des anges, ni de nôtre âme', Arnauld, Oeuvres 34, p. 304. 
The intellectual debate between those that supported the Jesuit claims and those who argued against them was reflected on the pages of learned journals. In January 169o, Henri Basnage de Beauval of the Histoire des ouvrages des savants reviewed Arnauld's Morale pratique des Jesuites. In this work, Arnauld attacked not so much the nature of Chinese thought, but what he supposed to be 'the fatally comprised Jesuit position in moral theology'.160 Arnauld attested that, although Ricci may have believed that the Chinese expression for 'material sky' in actuality meant 'true God', subsequent Jesuits like Longobardo already knew this to be wrong, but remained silent. As such, the Jesuits knew that the Chinese 'profess no religion, appear incapable of the most common reasoning that leads other men to true or false knowledge of a divinity', yet concealed it to further their mission. ${ }^{161}$ Furthermore, Arnauld was most appalled by what he believed to be the Jesuits' deliberate neglect of Christology (the ontology and person of Jesus), and the formative powers of the Crucifixion and subsequent Resurrection in their preaching in China. This, of course, was a harsh accusation as the Society of Jesus took its name and its principles from Christ.

A review of Arnauld's polemic could have found no better home than the Histoire des ouvrages, for the journal and its editor had long had a contentious relationship with Jesuit authors and their works. ${ }^{162}$ Since the Society of Jesus made contributions to almost every branch of scholarship, it comes as no surprise that Basnage reviewed many works written by Jesuit authors. ${ }^{163}$ In these reviews, Basnage focused almost solely on the conflicts in which the Jesuits were involved. Even when discussing works by authors who were not Jesuits themselves, the Society was cast in a less than favourable light. ${ }^{164}$ Regarding the Jesuits and their mission in China, Basnage proved firmly on Arnauld's side:

And the Jesuits for their part, who do not want to frighten the Gentiles by a too rigorous [form of] Christianity, or who themselves aspire to dignities that call for these kinds of precautions (as it is said that Father Martinus was high officer of the artillery), soften the severe laws of the Gospel by this tolerance for the weakness of the converted idolaters. This

\footnotetext{
16o Histoire des ouvrages des savants (January 169o), pp. 192-202.

161 Arnauld, Oeuvres, vol. xxxiv, pp. 697-697.

162 Gemert, 'De jezuïten in de "Histoire des ouvrages des savants", pp. 305-351.

163 Begheyn, Jesuit books in the Low Countries; Mordechai Feingold, 'Jesuits: Savants', in Mordechai Feingold (ed.), Jesuit science and the Republic of Letters (Cambridge and London: the MIT Press, 2003), pp. 1-47.

164 'La concurrence du commerce entre les Hollandois \& les Jesuïtes qui se sourrent partout, a été la premiere cause de ce changement', Histoire des ouvrages des savants (June 1689), pp. 324-328.
} 
scandalous policy has excited murmurs among the other missionaries, who could not have endured that the Christian religion was thus bargained through this strange union with Chinese superstitions. ${ }^{165}$

In October 1692, Basnage went a step further by reminding his readers that Matteo Ricci had been wrong in equating Xam ti with any European conception of God: 'Nevertheless, the truth is that Confucius recognized no spiritual being, and none distinct from matter, and that he attributed the creation of the world to the fortuitous movement of formless matter.'166

The mediating role of editor Basnage shaped the manner in which the polemic between Arnauld and the Jesuit missionaries was laid out before the burgeoning reading public. In the first sentence, Basnage spoke directly to his readers, noticing how 'in spite of the obstinate silence of the Jesuits, who have not replied to any of the three volumes [by Arnauld], by which they appear to have been overwhelmed', Mr. Arnauld is 'not at all discouraged. And [also], out of fear that they can no longer remain silent out of sagacity, or under the pretext of calling a halt to a trial that henceforth tires the world, he greatly attacks them on this point'. ${ }^{167}$ In the following paragraph, Basnage explicitly called upon 'the audience before whom this trial takes place to condemn them in absentia.' ${ }^{168}$ As Arnauld himself related: 'One should take their silence for an evasion and for acquiescence. This will be interpreted accordingly by most

165 'Et les Jesuites de leur côté, qui ne veulent point effaroucher les Gentils par un Christianisme trop rigoureux, ou qui aspirent eux-mêmes aux dignitez qui demandent ces sortes de ménagemens, comme l'on dit que le P. Martinius estoit Mandarin de l'artillerie, adoucissent les severes loix de l'Evangile par cette tolerance pour les foiblesses des idolatres convertis. Cette scandaleuse politique a excité les murmures des autres missionnaires, qui n'ont pû souffrir que l'on trafiquast ainsi de la Religion Chrêtienne, par cette union bizarre avec les superstitions Chinoises', Histoire des ouvrages des savants (January 169o), pp. 200-201.

166 'La verité est cependant que Confucius ne reconnoissoit aucun être spirituel, \& distinct de la matiere, \& qu'il attribuoit la construction du monde au mouvement fortuit de la matiere informe. Les Jesuïtes eux-même ont avoüé que c'est une erreur, qu'ils ont bien de la peine à deraciner de l'esprit des Chinois', Histoire des ouvrages des savants (October 1692), pp. 94-99.

167 'Malgré le silence opiniâtre des Jesuïtes, qui n'ont rien repliqué à trois Volumes dont ils * (voyez. Janvier \&Août 169o \& Avril 1691) ont été affaillis, Mr. Arnaud ne se rebute point: \& de peur qu'ils ne viennent à bout de persuader qu'ils se taisent par sagesse, ou sous pretexte de laisser 'teindre un procés qui fatigue desormais le monde, il les tourmente fort sur cet article', Histoire des ouvrages des savants (October 1692), pp. 94-99 (my emphasis).

168 'Le public devant qui le procés se poursuit, les condamne par contumace', Histoire des ouvrages des savants (October 1692), pp. 94-99. 
people, of whom one has become accustomed to believe everything about the Jesuits without further examination'.169

In the last decade of the seventeenth century, the problems of how to reconcile Confucius's supposed atheism with admiring accounts of his virtue as a Chinese sage were often publicly debated on the pages of Dutch-made learned journals. On one side stood the Jesuits, who were in favour of Confucianism, attributing to its sage 'a morality that might be said to proceed from the school of Jesus Christ. ${ }^{170}$ In their accommodation policy and the subsequent translation of the Confucian classics, the Jesuits were certainly partly motivated by a genuine interest in China, as their works often combined justifications of respectable Confucianism with extensive cultural praise. However, their European opponents, like Antoine Arnauld, not so much objected to the nature of Chinese thought, but what they took to be the fatally compromised Jesuit position in moral theology. ${ }^{171}$

These objections tied in with the bitter Jansenist-Jesuit polemics that were simultaneously taking place in France. As such, China and Confucius Sinarum philosophus became another way to attack the Society of Jesus. The flourishing reading public of learned journals was provided with extensive coverage of the issues, as the debate had apparently caught their interest. These journals also filled gaps in available knowledge. For instance, if the public missed Arnauld's rather lengthy exposition against the Jesuits, they had access to the sympathetic review of his work in the Histoire des ouvrages des savants.

During the second half of the seventeenth century, Dutch-made learned journals in French played an essential role in the intellectual dissemination of images of Chinese religion and philosophy. Their international scope facilitated widespread access to discussions about the meaning and interpretation of Confucius and the Jesuit policy of accommodation across cultural, societal, and linguistic boundaries. The erudite press spread news and knowledge more quickly than books, and more widely than correspondence; for the first time, China truly became the subject of broad public discussion.

This chapter investigated how learned journals in the United Provinces represented China and Confucius, and how the involvement of Dutch book producers helped construct the narrative of the Middle Kingdom and its religion and philosophy as an intellectual phenomenon. The erudite press influenced the early modern debate on China from two directions: from within by

\footnotetext{
169 'On prenne leur silence pour une fuite, \& pour un acquiescement. Cela sera interpreté de même par bien des gens, que l'on a accoutumez à tout croire des Jesuïtes sans autre examen', Historie des ouvrages des savants (October 1692), pp. 94-99.

170 Couplet, Confucius Sinarum philosophus, p. xcvii.

171 Kors, Atheism in France, pp. 163-165.
} 
way of publishing strategies aimed at the Republic of Letters, and externally through peritext, most obviously the Chinese Rites Controversy and the comparison between European radical thought and the teachings of Confucius. Contributors and editors employed various forms of transtextuality, such as quotation, genre, and critical commentary, in their reaction to and interpretation of Confucius Sinarum philosophus and the Jesuit representation of Confucius. The integrated analysis of these reviews and the original Latin book has made clear that religious, political, and intellectual conjunctures weighed heavily on images of Chinese religion and philosophy during the last decades of the seventeenth century.

As 'print-versions' of information that was exchanged with the Republic of Letters, learned journals performed an invaluable function in the spread of intellectual and scholarly discourse. The Dutch Republic produced a greater number of titles than any other European country and, as such, provided an important service to European scholarship. Its quality was highly esteemed, and Dutch printers and publishers thus had a pivotal function in the international exchange of news and information about China. In this exploration of Dutch-made journals, we find publishers' strategies aimed at a growing readership of intellectuals who were part of the Republic of Letters, while simultaneously drumming up demand for their own publications. When French became the European language of letters and culture, the Dutch soon adapted. Concerning China, this development was aided by an influx of Huguenot refugees after 1685, and the French Jesuit mission to China sent by Louis XIV in the late 168 os.

In the third quarter of the century, China became a subject of growing intellectual importance. In reviewing books and information about the Middle Kingdom, learned journals spread discussions on the country and its religion and philosophy far and wide. Here, the role of the editor facilitated public conversation; in this important capacity, he functioned as a gatekeeper of information. When, in 1687, Confucius Sinarum philosophus was published in Paris, it was discussed extensively in the learned press; in fact, it was the only work reviewed in all major journals in that year. While these reviews seemed favourable at first, further analysis in this chapter has demonstrated that the (often) Huguenot editors were rather critical about the Jesuit translation and their interpretation of Confucius. Here, not only ideological and religious consideration played their part, reviews were also shaped by economic rules of cultural consumption and publishing strategies. This chapter noted also that the sale of books and their reviews in learned journals often worked in commercial tandem. This form of bias continues in the editors' discussions of Confucius Sinarum philosophus, in which personal opinions often shone through. As they reviewed both content and interpretation of the Jesuit translation of Confucius, 
it soon becomes clear that it was particularly the Society of Jesus and their mission in China that were the points of contention. Editors sometimes proved more critical of the manner in which information about Confucius was presented, and by whom, than by its philosophical or religious consequences.

However, the consequences of the increasing cultural contacts between China and Europe were certainly on the minds of a small number of primarily Protestant intellectuals, proving that polemics concerning the Middle Kingdom often went beyond issues of religious affiliation. In particular, the issues concerning the antiquity of China and biblical chronology found their way to the pages of these learned journals. Calvinist Isaac Vossius was the main proponent of the debate over chronology from the 166os onwards. He soon became embroiled in a war of pamphlets with fellow Calvinist Georg Hornius, who tried to refute Vossius claim that the Flood had not been universal and that the Septuagint Bible should be used as authority rather than the Hebrew text. Notably, only Vossius works were translated into Dutch. The debate between Calvinists Isaac Vossius and Georg Hornius is emblematic of the battle over biblical chronology for which China was employed as a kind of 'cannon fodder'. In this war of pamphlets. China and Confucius were considered as viable intellectual avenues of enquiry.

The writings of French Jansenist and vehement Jesuit detractor Antoine Arnauld were also extensively discussed in Dutch learned journals. He was one of the first to formulate a clear critique of the Jesuit interpretation of Confucius and his teachings, specifically taking umbrage with China's alleged atheism that, according to Arnauld, was deliberately hidden from view by the Jesuits. Again, the editor (in this case Henri Basnage de Beauval of the Histoire des Ouvrages) performed an important mediating role between contributor and reader by presenting (often not entirely impartially) the issue on the pages of the learned journal. This chapter has revealed the editor as a major driving influence in shaping not only the representation of China and Confucius in Dutch learned journals, but also the discussion of the Middle Kingdom as an intellectual phenomenon worthy of consideration.

Over the course of the seventeenth century, learned journals were not the only form of periodical print discussing China. The next chapter turns to newspapers and news digests printed in the Dutch Republic. Unlike erudite journals, these also appeared in Dutch and, as such, took often quite divergent approached towards the Middle Kingdom, according to the intended audience envisaged. Additionally, the Chinese Rites Controversy became a major public issue at the turn of the century. Various Jesuit books on the subject, and their subsequent censure by Catholic authorities in Paris and Rome, were discussed extensively in both Dutch and French newspapers produced in the United Provinces. 